\title{
MALTE - model to predict new aerosol formation in the lower troposphere
}

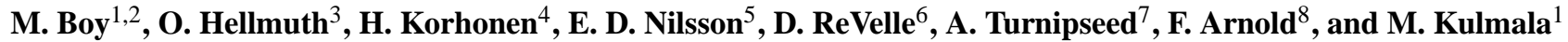 \\ ${ }^{1}$ Department of Physical Sciences, Division of Atmospheric Sciences, P.O. Box 64, 00014 University of Helsinki, Finland \\ ${ }^{2}$ ASP/ACD, NCAR, P.O. Box 3000, 80305 Boulder, Colorado, USA \\ ${ }^{3}$ Leibniz Institute for Tropospheric Research, Permoserstrasse 15, 04318 Leipzig, Germany \\ ${ }^{4}$ Finnish Meteorological Institute, Air Quality Research, Sahaajankatu 20 E, 00880 Helsinki, Finland \\ ${ }^{5}$ Department of Meteorology, Stockholm University, 10691 Stockholm, Sweden \\ ${ }^{6}$ Earth and Environmental Sciences, Los Alamos National Lab., P.O. Box 1663, MS D401, Los Alamos, NM, 87545 USA \\ ${ }^{7}$ ACD, NCAR, P.O. Box 3000, 80305 Boulder, Colorado, USA \\ ${ }^{8}$ Atmospheric Physics Division, Max-Planck Institute for Nuclear Physics (MPIK), P.O. Box 103980, 69029 Heidelberg, \\ Germany
}

Received: 13 February 2006 - Published in Atmos. Chem. Phys. Discuss.: 4 May 2006

Revised: 12 September 2006 - Accepted: 25 September 2006 - Published: 6 October 2006

\begin{abstract}
The manuscript presents a detailed description of the meteorological and chemical code of Malte - a model to predict new aerosol formation in the lower troposphere. The aerosol dynamics are achieved by the new developed UHMA (University of Helsinki Multicomponent Aerosol Model) code with kinetic limited nucleation as responsible mechanism to form new clusters. First results indicate that the model is able to predict the on- and offset of new particle formation as well as the total aerosol number concentrations that were in good agreement with the observations. Further, comparison of predicted and measured $\mathrm{H}_{2} \mathrm{SO}_{4}$ concentrations showed a satisfactory agreement. The simulation results indicated that at a certain transitional particle diameter $(2-7 \mathrm{~nm})$, organic molecules can begin to contribute significantly to the growth rate compared to sulphuric acid. At even larger particle sizes, organic molecules can dominate the growth rate on days with significant monoterpene concentrations. The intraday vertical evolution of newly formed clusters and particles in two different size ranges resulted in two maxima at the ground. These particles grow around noon to the detectable size range and agree well with measured vertical profiles.
\end{abstract}

Correspondence to: $\mathrm{M}$. Boy

(michael.boy@helsinki.fi)

\section{Introduction}

New secondary particle formation has been observed at almost all places where both particle number concentrations and size distributions have been measured; a comprehensive summary of these studies is given in Kulmala et al. (2004a). However, many questions currently remain regarding the extent to which these secondary aerosols can influence climate, radiative properties and human health. There is growing evidence that the Earth's radiation budget is affected by radiative forcing caused by changes in the number concentration and composition of aerosols (Lohmann and Feichter, 2005; Ramanathan et al., 2001). In addition higher number concentrations of ultrafine particles could have a strong impact on the size distribution of cloud condensation nuclei, which will further affect cloud properties (Kerminen et al., 2005).

Even though many field campaigns, laboratory experiments and new modelling approaches have improved our understanding to some extent, detailed mechanisms responsible for the formation of new particles in the planetary boundary layer are still not completely elucidated to date. Here we merged individually developed codes into a one-dimensional model including aerosol dynamics, boundary layer meteorology and chemistry in order to investigate the formation and growth processes responsible for the secondary organic aerosols under realistic atmospheric conditions. Up to our knowledge this is the first approach to combine aerosol dynamics, chemistry and meteorology in a one-dimensional model to investigate the different mechanisms included in the formation of secondary organic aerosols in the planetary boundary layer.

Published by Copernicus GmbH on behalf of the European Geosciences Union. 


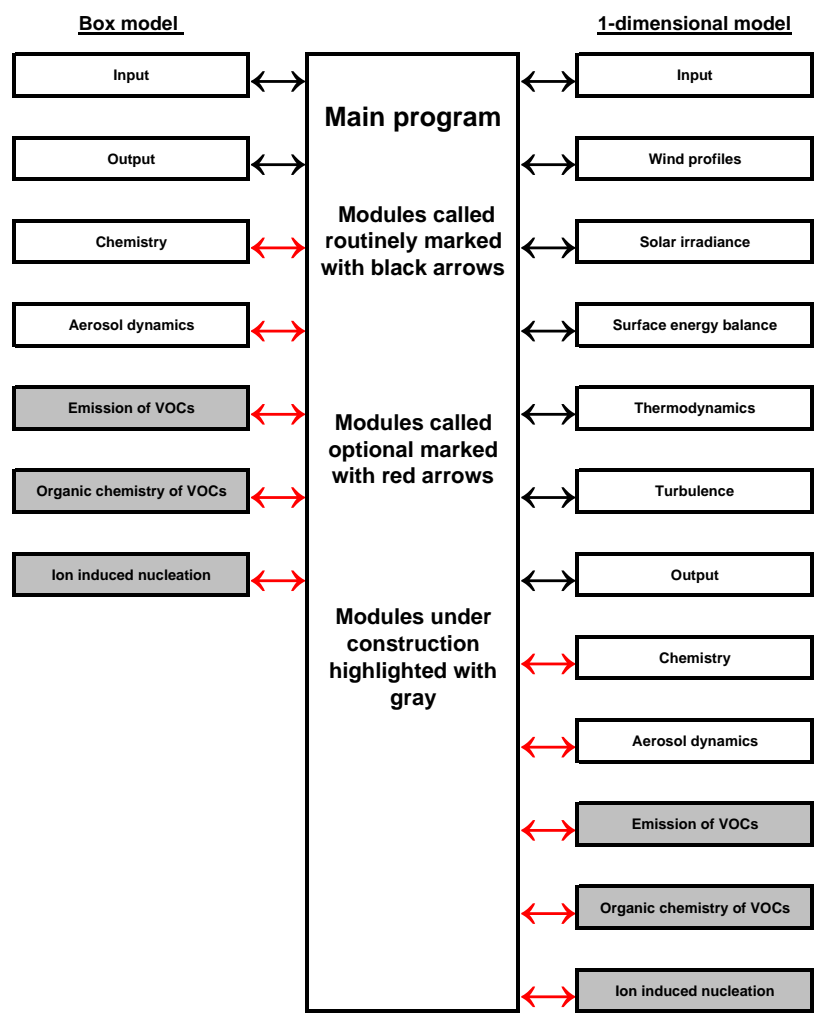

Fig. 1. Schematic diagram of the model MALTE.

\section{Model description}

\subsection{Model overview}

MALTE is a one-dimensional model which includes several modules for the simulation of boundary layer dynamics and both chemical and aerosol dynamical processes. Owing to the modular structure, a number of sub-models can be alternatively switched on/off depending on the question of interest. This modular nature also facilitates use and testing and offers the possibility to quantify possible impacts and interactions. For example, MALTE can be used as a simple box-model to simulate chamber experiments. Figure 1 shows the basic schematic of the model. Some of these parts are currently under construction and will not be described here (highlighted with gray in Fig. 1). MALTE divides the planetary boundary layer (PBL) into several layers. The number and thickness of the model layers are variable, typically dependent on the availability of sounding measurements which are used to initialize the model. For the timedependent integration of the chemical and aerosol processes, a Runge-Kutta scheme is used (Press, 1992). In the following, the model description of the meteorological, chemical, and aerosol-dynamical processes will be presented.

\subsection{Planetary boundary layer model}

\subsubsection{Governing equations}

For the description of Planetary Boundary Layer (PBL) processes, a first-order closure technique is applied. The PBL model includes predictive equations for four first statistical moments (means), i.e., the $\mathrm{x}$ - and y-component of the wind $\bar{u}$ and $\bar{v}$, the potential temperature $\bar{\theta}$ and the specific humidity $\bar{q}$. The model is mainly based on the previous works of Blackader (1979) and ReVelle (1993). It considers geostrophic wind forcing, radiative forcing, and large-scale subsidence. Assuming horizontal homogeneity, the governing equations in an Eulerian reference system are:

$$
\begin{aligned}
& \frac{\partial \bar{u}}{\partial t}+\bar{w}_{s} \frac{\partial \bar{u}}{\partial z}=-\frac{\partial \overline{w^{\prime} u^{\prime}}}{\partial z}+f_{c}\left(\bar{v}-\bar{v}_{g}\right) \\
& \frac{\partial \bar{v}}{\partial t}+\bar{w}_{s} \frac{\partial \bar{v}}{\partial z}=-\frac{\partial \overline{w^{\prime} v^{\prime}}}{\partial z}-f_{c}\left(\bar{u}-\bar{u}_{g}\right) \\
& \frac{\partial \bar{\theta}}{\partial t}+\bar{w}_{s} \frac{\partial \bar{\theta}}{\partial z}=-\frac{\partial \overline{w^{\prime} \theta^{\prime}}}{\partial z}+\left(\frac{\partial \bar{\theta}}{\partial t}\right)_{r a d} \\
& \frac{\partial \bar{q}}{\partial t}+\bar{w}_{s} \frac{\partial \bar{q}}{\partial z}=-\frac{\partial \overline{w^{\prime} q^{\prime}}}{\partial z}
\end{aligned}
$$

Here, $f_{c}=2 \omega \sin \Phi$ denotes the Coriolis parameter with $\omega=7.27 \times 10^{-5} \mathrm{~s}^{-1}$ being the angular velocity of the Earth's rotation, and $\Phi$ being the geographical latitude. The variables $u_{g}$ and $v_{g}$ are the $\mathrm{x}$ - and respective y-component of the geostrophic wind, and $w_{s}$ is the large-scale subsidence velocity. The turbulent fluxes of momentum (longitudinal and lateral to the mean wind), sensible heat, and humidity are $\overline{w^{\prime} u^{\prime}}, \overline{w^{\prime} v^{\prime}}, \overline{w^{\prime} \theta^{\prime}}$ and $\overline{w^{\prime} q^{\prime}}$, respectively.

According to the annotation of Stull (1997, Subsect. 6.4, p. 203-204), a first order/local closure is applied, i.e., the second moments are parameterised according to the downgradient approximation or "K-theory":

$$
\begin{aligned}
& \overline{w^{\prime} u^{\prime}}=-K_{m} \frac{\partial \bar{u}}{\partial z}, \overline{w^{\prime} v^{\prime}}=-K_{m} \frac{\partial \bar{v}}{\partial z}, \overline{w^{\prime} \theta^{\prime}}=-K_{h} \frac{\partial \bar{\theta}}{\partial z}, \\
& \overline{w^{\prime} q^{\prime}}=-K_{h} \frac{\partial \bar{q}}{\partial z}
\end{aligned}
$$

Here $K_{m}$ and $K_{h}$ denote the eddy diffusivities for momentum and scalars, respectively.

\subsubsection{Prandtl layer parameterization}

The Prandtl layer model is based on Blackadar (1979) and ReVelle (1993). A comprehensive motivation and explanation of the present realisation of that model, called "Blackadar system" can be found in ReVelle (1993). A key assumption is the fact, that "the near-surface air temperature 
change is controlled by a combination of radiative and turbulent forcing as a function of the flow regime of the nearsurface PBL." The Prandtl layer is subdivided into two layers. The first layer extends from the ground level up to the height $z_{1}=1 \mathrm{~m}$. In this near-surface layer the flow is quasilaminar and atmospheric radiation effects become important for the thermal flow structure. Hence, this layer is named "radiation-surface layer". The second layer reaches from the level $z_{1}$ up to the level $z_{2}=10 \mathrm{~m}$, with $z_{2}$ denoting the top of the Prandtl layer being identical to the first regular model level. In this layer the flow is turbulent and only turbulent heating and cooling controls the vertical structure of the wind and temperature fields, but not radiation. Thus, this layer is named "turbulence-surface layer". The Blackadar system includes governing equations for the Prandtl layer air potential temperature $\bar{\theta}_{1}$ at $z_{1}=1 \mathrm{~m}$, and the components of the wind velocity $\bar{u}_{2}$ and $\bar{v}_{2}$, respectively, within the Prandtl layer. Additionally, further equations for the determination of the ground surface interface potential temperature $\bar{\theta}_{g}$ and the "deep" ground potential temperature, $\bar{\theta}_{m}$, representing the temperature at the depth of penetration and the diurnal heating-cooling cycle, are considered. The final set of equations, except for the soil properties, read:

$$
\begin{aligned}
& \frac{\partial \overline{\theta 1}}{\partial t}=a\left(\bar{\theta}_{g}-\bar{\theta}_{1}\right)-b \frac{H_{0}}{\rho c_{p} z_{1}} \\
& \frac{\partial \bar{u}_{2}}{\partial t}=-\left.\frac{\partial \overline{w^{\prime} u^{\prime}}}{\partial z}\right|_{2}+f_{c}\left(\bar{v}_{2}-v_{g}\right) \\
& \frac{\partial \bar{v}_{2}}{\partial t}=-\left.\frac{\partial \overline{w^{\prime} v^{\prime}}}{\partial z}\right|_{2}-f_{c}\left(\bar{u}_{2}-u_{g}\right)
\end{aligned}
$$

The model parameters are the turbulent flux of sensible heat $H_{0}=-\kappa \rho c_{p} u * \theta *$ in $\left[\mathrm{W} \mathrm{m}^{-2}\right]$, an inverse adjustment time scale $a=0.32 \varepsilon \sigma \bar{\theta}_{a}^{3} /\left(\rho c_{p} z_{1}\right)$ in $\left[\mathrm{s}^{-1}\right]$, a dimensionless empirical constant $b=0.2$, the surface emissivity $\varepsilon$, the Stefan-Boltzmann constant $\sigma=5.67 \times 10^{-8} \mathrm{Wm}^{-2} \mathrm{~K}^{-4}$, the von-Karman constant $\kappa=0.4$, the air density $\rho$ in $\left[\mathrm{kg} \mathrm{m}^{-3}\right]$, the specific heat capacity of moist air $c_{p}$ in $\left[\mathrm{J} \mathrm{kg}^{-1} \mathrm{~K}^{-1}\right]$, the friction velocity $u_{*}=\left.\left(\overline{w^{\prime} u^{\prime}}\right)\right|_{s}+\left.\left(\overline{w^{\prime} v^{\prime}}\right)\right|_{s} ^{\frac{1}{4}}$, the kinematic temperature scale $\theta_{*}=\left.\overline{w^{\prime} \theta^{\prime}}\right|_{s} / u_{*}$.

The divergences of the turbulent momentum fluxes in the Prandtl layer can be approximated as follows:

$$
\begin{gathered}
\left.\frac{\partial \overline{w^{\prime} u^{\prime}}}{\partial z}\right|_{2} \approx \frac{\left.\overline{w^{\prime} u^{\prime}}\right|_{2}-\left.\overline{w^{\prime} u^{\prime}}\right|_{1}}{\Delta z} \\
\left.\frac{\partial \overline{w^{\prime} v^{\prime}}}{\partial z}\right|_{2} \approx \frac{\left.\overline{w^{\prime} v^{\prime}}\right|_{2}-\left.\overline{w^{\prime} v^{\prime}}\right|_{1}}{\Delta z}
\end{gathered}
$$

with $\Delta z=z_{2}-z_{1}$ being the height difference between the top of the Prandtl layer (level 2) and the top of the radiationsurface layer (level 1). Using the following approximations (Stull, 1997, p. 262)

$$
\begin{aligned}
& \left.\overline{w^{\prime} u^{\prime}}\right|_{1} \approx-C_{d}(\xi) V_{H} u_{2} \\
& \left.\overline{w^{\prime} v^{\prime}}\right|_{1} \approx-C_{d}(\xi) V_{H} v_{2} \\
& \overline{\left.w^{\prime} u^{\prime}\right|_{2}} \approx-K_{m} \frac{\Delta u_{2}}{\Delta z} \\
& \overline{\left.w^{\prime} v^{\prime}\right|_{2}} \approx-K_{m} \frac{\Delta v_{2}}{\Delta z}
\end{aligned}
$$

with $V_{H}=\left(u_{2}^{2}+v_{2}^{2}\right)^{\frac{1}{2}}$ being the horizontal wind velocity at $z_{2}, C_{d}(\xi)$ the drag coefficient as a function of the dimensionless stability parameter $\xi=z / L$, and $L$ the Monin-Obukhov length (Stull, 1997, p. 265-269). Substitution into Eqs. (7) and (8), one obtains

$$
\begin{aligned}
& \frac{\partial \bar{u}_{2}}{\partial t}=K_{m} \frac{\Delta \bar{u}_{2}}{\Delta z^{2}}-\frac{C_{d}(\xi) V_{H} u_{2}}{\Delta z}+f_{c}\left(\bar{v}_{2}-v_{g}\right) \\
& \frac{\partial \bar{v}_{2}}{\partial t}=K_{m} \frac{\Delta \bar{v}_{2}}{\Delta z^{2}}-\frac{C_{d}(\xi) V_{H} v_{2}}{\Delta z}-f_{c}\left(\bar{u}_{2}-u_{g}\right)
\end{aligned}
$$

\subsubsection{Adjustment of the parameterisation to flow stability}

With the assumption of Monin-Obukhov similarity in the Prandtl layer, the potential temperature difference $\left(\bar{\theta}_{2}-\bar{\theta}_{1}\right)$, the specific humidity difference $\left(\bar{q}_{2}-\bar{q}_{1}\right)$, and the wind velocity $V_{H}$ at $z_{2}$ can be determined from the kinematic temperature scale, $\theta_{*}$, the kinematic humidity scale, $q_{*}$, and the friction velocity, $u_{*}$. (Remember $z_{1}$ denotes the top of radiationsurface layer, and $z_{2}$ the top of the Prandtl layer and first regular main level.) A direct solution of the inverse problem, i.e., the determination of $\theta_{*}, q_{*}$, and $u_{*}$ from the gridscale temperature and specific humidity at $z_{1}$ and $z_{2}$ and the wind at $z_{2}$ is possible, but for practical reasons not feasible. Alternatively, the scaling properties must be determined by numerical iteration. Owing to the availability of good initial estimates of $u_{*}, \theta_{*}$ and $q_{*}$ from the previous time step, a double-iteration routine is sufficient to produce accurate updated values (Blackadar, 1979, p. 70-71). Again, following Blackadar (1979), we adjust the kinematic Prandtl layer scaling properties $u_{*}, \theta_{*}$ and $q_{*}$ to the flow stability, allowing us to evaluate the turbulent-to-laminar flow transition. At first, the bulk Richardson number $R i_{B}$ of the Prandtl layer is evaluated between $z_{1}$ and $z_{2}$ using the most recently available values of $\bar{\theta}_{1}, \bar{\theta}_{2}, V_{H}\left(z_{2}\right)$ and $\theta_{*}$ i.e.,

$R i_{B}=\left(\frac{g}{\bar{\theta}_{\text {avg }}}\right)\left(\frac{z_{2}}{V_{H}^{2}}\right)\left[\bar{\theta}_{2}-\bar{\theta}_{1}+\theta_{*} \ln \left(\frac{z_{1}}{z_{0}}\right)\right]$

with

$\bar{\theta}_{\text {avg }}=\left(\bar{\theta}_{1}+\bar{\theta}_{2}\right) / 2$ 
and $g=9.80665 \mathrm{~m}^{2} \mathrm{~s}^{-1}$ being the constant of gravity, and $z_{0}$ the aerodynamic roughness length (Blackadar, 1979, Eq. 5.10). According to the values of $R i_{B}$ three different regimes can be distinguished:

(a) $R i_{B}>0.2$ :

In this case the lowest layer becomes non-turbulent, and even though the wind velocity at the level $z_{2}$ is not zero, the momentum fluxes at the surface are set to zero. Then, the kinematic temperature scale $\theta_{*}$ as well as the stability functions for momentum and heat transfer $\Psi_{m}$ and $\Psi_{h}$ are set to zero, hence $H_{0}=0$. For the friction velocity a minimum value of $u_{*}=0.05 \mathrm{~ms}^{-1}$ is assumed. The turbulent humidity "mass" flux $Q_{0}$ in $\left[\mathrm{kg} \mathrm{m}^{-2} \mathrm{~s}^{-1}\right]$ is reduced to the molecular flux according to

$Q_{0} \approx Q_{0, m o l}$

$Q_{0, m o l}=-m_{a} \rho K_{h, m o l}\left(\frac{q_{2}-q_{1}}{h-z_{0}}\right)$

With $Q_{0, \text { mol }}$ being the molecular humidity mass flux, $m_{a}$ being the moisture availability at the surface, i.e., the efficiency of evaporation (0-1), $K_{h, \text { mol }}=2.4 \times 10^{-5} \mathrm{~m}^{2} \mathrm{~s}^{-1}$ the molecular eddy diffusivity for scalars, and $h$ being a characteristic Prandtl layer length scale (Lettau's length scale)

$h=\left(z_{1} z_{2}\right)^{\frac{1}{2}}$

The kinematic humidity scale reads

$q_{*}=-\frac{Q_{0}}{\rho u_{*}}$

(b) $0 \leq R i_{B} \leq 0.2$ :

In the case of stable but turbulent flow the Monin-Obukhov length is determined from the following equation (Blackadar, 1979, Eq. 5.11):

$\frac{1}{L}=\frac{1}{h} \ln \left(\frac{h}{z_{0}}\right)\left(\frac{R i_{B}}{1-5 R i_{B}}\right)$

Then, the kinematic scaling properties are (Blackadar, 1979, Eqs. 5.12-5.13):

$$
\begin{aligned}
& u_{*}=\frac{\left.\kappa V_{H}\right|_{z_{2}}}{\ln \left(\frac{h}{z_{0}}\right)-\psi_{m}} \\
& \theta_{*}=\frac{\bar{\theta}_{2}-\bar{\theta}_{1}}{\ln \left(\frac{h}{z_{0}}\right)-\psi_{h}} \\
& q_{*}=\frac{\bar{q}_{2}-\bar{q}_{1}}{\ln \left(\frac{h}{z_{0}}\right)-\psi_{h}} \\
& q_{1}=q_{g}+\left(\frac{q_{2}-q_{g}}{z_{2}}\right) z_{1}
\end{aligned}
$$

$$
\begin{aligned}
& \psi_{m}=-\frac{5 h}{L} \\
& \psi_{h}=\psi_{m} \\
& H_{0}=-\kappa c_{p} \rho u_{*} \theta_{*} \\
& Q_{0}=Q_{0, m o l}-m_{a} \rho \kappa u_{*} q_{*}
\end{aligned}
$$

with $q_{g}$ being the specific humidity at the surface, i.e.,

$q_{g}=m_{a} q_{g, s a t}+\left(1-m_{a}\right) q_{2}$

and $q_{g, s a t}$ the saturation specific humidity at $z=0$. The latter is a function of the saturation vapour pressure of water at $z=0$ and the surface air pressure.

(c) $R i_{B}<0$ :

In the unstable case the last estimate of the Monin-Obukhov length is used to evaluate the scaling properties (Blackadar, 1979, Eqs. 5.15-5.20, see references therein):

$$
\begin{aligned}
& u_{*}=\frac{\left.\kappa V_{H}\right|_{z_{2}}}{\ln \left(\frac{h}{z_{0}}\right)-\psi_{m}} \\
& \theta_{*}=\frac{\bar{\theta}_{2}-\bar{\theta}_{1}}{\ln \left(\frac{h}{z_{0}}\right)-\psi_{h}} \\
& q_{*}=\frac{\bar{q}_{2}-\bar{q}_{1}}{\ln \left(\frac{h}{z_{0}}\right)-\psi_{h}}
\end{aligned}
$$

$q_{1}=q_{g}+\left(\frac{q_{2}-q_{g}}{z_{2}}\right) z_{1}$

$\psi_{m}=\frac{\psi_{h}+\pi}{2}+2 \ln \left(\frac{1+x}{2}\right)-2 \tan ^{-1} x$

$$
\begin{aligned}
& \psi_{h}=2 \ln \left(\frac{1+x^{2}}{2}\right) \\
& x=\left(1-16 \frac{h}{L}\right)^{\frac{1}{4}} \\
& \frac{1}{L}=\left(\frac{R i_{B}}{h}\right)\left(\frac{\left[\ln \left(h / z_{0}\right)-\psi_{m}\right]^{2}}{\ln \left(h / z_{0}\right)-\psi_{h}}\right)
\end{aligned}
$$

$H_{0}=-\kappa c_{p} \rho u_{*} \theta_{*}$

$Q_{0}=Q_{0, m o l}-m_{a} \rho \kappa u_{*} q_{*}$ 


\subsubsection{Soil-slab model}

For the determination of the ground temperature $\bar{\theta}_{g}$, the soilslab model proposed by Blackadar (1979, Appendix) is used (see ReVelle (1993) as well). It is very similar to the "forcerestore method", such as described, e.g., in Stull (1997, p. 285-287). The governing equations for $\bar{\theta}_{g}$ are

$c_{g} \frac{\partial \theta_{g}}{\partial t}=E-G$

$E=K^{\downarrow}-K^{\uparrow}+L^{\downarrow}-L^{\uparrow}-H_{0}-L_{v} Q_{0}$

$G=\kappa m c_{g}\left(\bar{\theta}_{g}-\bar{\theta}_{m}\right)$

with $E$ being the energy flux input into the soil slab of uniform properties $\left[\mathrm{Wm}^{-2}\right], K^{\downarrow}$ the downward directed shortwave radiation flux $\left[\mathrm{Wm}^{-2}\right], K^{\uparrow}=\alpha K^{\downarrow}$ the upward directed shortwave radiation flux, $\alpha_{g}$ the surface albedo, $L^{\downarrow}=5.31 \times 10^{13} \bar{\theta}_{a}^{6}\left[\mathrm{Wm}^{-2}\right]$, the downward long-wave radiation flux (back-radiation flux from the atmosphere) (Swinbank, 1963), $L^{\uparrow}=\varepsilon \sigma \bar{\theta}_{g}^{4}$ the outgoing long-wave radiation flux $\left[\mathrm{Wm}^{-2}\right]$ according to the Stefan-Boltzmann law, $L_{v}$ the specific latent heat of phase change $\left[\mathrm{J} \mathrm{kg}^{-1}\right], G$ the soil heat flux, $\bar{\theta}_{m}$ the potential temperature of the "deep" ground, i.e., representing the mean temperature of the slab and thus of the surface air during the most recent past, $\kappa_{m}$ an inverse adjustment time scale $\left[\mathrm{s}^{-1}\right]$, and $c_{g}=c_{s} d_{p}$ the heat capacity per unit volume $c_{s}$ integrated over the thickness of the soil slab $d_{p}$ (penetration depth) $\left[\mathrm{J} \mathrm{K}^{-1} \mathrm{~m}^{-2}\right]$ (heat capacity per unit area of the slab). Blackadar (1979, Appendix, A.15) derived semi-empirical expressions for the $c_{g}$ and $\kappa_{m}$, both in terms of the angular velocity of the Earth's rotation $\omega\left[\mathrm{s}^{-1}\right]$, the thermal conductivity of the soil layer $\lambda\left[\mathrm{W} \mathrm{m}^{-1} \mathrm{~K}^{-1}\right]$, and the heat capacity per unit volume of soil $c_{s}\left[\mathrm{~J} \mathrm{~K}^{-1} \mathrm{~m}^{-3}\right]$,

$\kappa_{m}=1.18 \omega$

$c_{g}=0.95\left(\frac{\lambda c_{s}}{2 \omega}\right)^{\frac{1}{2}}$

\subsubsection{Eddy diffusivity parameterization}

In the basic version, the eddy diffusivity coefficients for momentum $K_{m}$ and scalars $K_{h}$ are diagnostically parameterised according to an approach proposed by Blackadar (1979, Eqs. 4.18-4.19, see references therein). This closure scheme is essentially based on a level-2-approximation of the governing equations of a turbulent PBL flow according to the annotation of Mellor and Yamada (1974). The basic assumptions are horizontal homogeneity, stationarity, and that the advective and diffusive terms are negligible. The Mellor/Yamadalevel-2 approximation is known for not achieving MoninObukhov similarity. To overcome this problem Blackadar (1979) revised this scheme to improve its usefulness, especially to restore the Monin-Obukhov similarity. The authors rewrote the set of approximative level-2 equations with substitutions for the original length scales and introduction of new empirically derived parameters, which originate from the effect of vortex stretching and buoyancy adjustment on the pressure-correlation terms. Mellor and Yamada, e.g., did not include the effects of buoyancy adjustment. From an algebraic solution of eight revised diagnostic equations, Blackadar (1979) obtained flux-gradient relations to parameterise the turbulent heat and momentum flux as well as the Richardson number for stable, neutral, and unstable conditions.

Apart from the basic turbulence scheme, there are a number of additional options in MALTE for the eddy diffusivity parameterisation, based on semi-empirical and ad-hoc profile methods, such as those proposed by Holtslag et al. (1995), Lüpkes and Schlünzen (1996), Degrazia et al. (1997a, b, $1998,2001)$. In all of them, the mixing height $z_{i}$ serves as a characteristic length scale in the convective boundary layer (CBL). Here, the determination of $z_{i}$ is based on the bulk Richardson number according to the approach proposed by Holtslag et al. (1995, Eqs. 9-10, and Appendix).

\subsubsection{Radiative forcing}

The radiative forcing throughout the PBL due to the divergence of shortwave and long-wave radiative fluxes is parameterised according to Kondo and Matsushima (1993). The parameterisation uses the surface temperature and the temperature at $1 \mathrm{~m}$ along with the vertical profiles of water vapour and carbon dioxide to estimate the heating/cooling rate due to longwave radiation in the boundary layer.

\subsection{Chemical mechanism}

The chemistry module is solved for every height level and consists of 70 species, with 123 chemical and 16 photochemical reactions. Chemical loss, production and deposition are taken into account. All chemical species are listed in Table 1 along with their deposition velocities and initialisation values. With the exception of sulphuric acid (which is treated separately), the mass balance equation of each species is:

$$
\begin{gathered}
\frac{\partial \bar{C}_{i}}{\partial t}+w_{s} \frac{\partial \bar{C}_{i}}{\partial z}=-\frac{\partial \overline{w^{\prime} C_{i}^{\prime}}}{\partial z}+\bar{P}_{i}-\bar{L}_{i} \bar{C}_{i}+\left(\frac{\partial \bar{C}_{i}}{\partial t}\right)_{d e p} \\
\left.\left(\frac{\partial \bar{C}_{i}}{\partial t}\right)\right|_{d e p, z=z_{2}}=-\frac{\left(\overline{w^{\prime} C_{i}^{\prime}}\right)_{d e p}}{z_{2}-z_{1}}=-\frac{v_{d e p} \bar{C}_{i}}{z_{2}-z_{1}}
\end{gathered}
$$

where $C_{i}$ is the concentration of species $i, P_{i}$ is the chemical product rate, $L_{i} C_{i}$ is the chemical loss rate, $v_{d e p}$ is the deposition velocity and $z_{2}-z_{1}$ is the thickness of the first layer. 
Table 1. List of gases, their initialization concentration and the deposition velocity.

\begin{tabular}{|c|c|c|c|c|c|c|}
\hline \multirow{3}{*}{ Nr. } & \multirow{2}{*}{\multicolumn{2}{|c|}{ Gas specie }} & \multirow{3}{*}{$\begin{array}{c}\text { Initialization } \\
{\left[\# \mathbf{c m}^{-3}\right]}\end{array}$} & \multicolumn{3}{|c|}{ Deposition } \\
\hline & & & & \multirow{2}{*}{$\frac{\text { Day }}{\left[\mathrm{m} \mathrm{s}^{-1}\right]}$} & \multirow{2}{*}{$\frac{\text { Night }}{\left[\mathrm{m} \mathrm{s}^{-1}\right]}$} & \multirow[b]{2}{*}{ Reference } \\
\hline & Formula & Common name & & & & \\
\hline 1 & $\mathrm{O}_{3}$ & ozon & measurements & 0.008 & 0.0015 & Mikkelson et al., 2004 \\
\hline 2 & $O\left({ }^{1} D\right)$ & atomic oxygen (excited state) & 0 & \multicolumn{2}{|c|}{ too reactive } & reacts with $\mathrm{N}_{2}, \mathrm{O}_{2}, \mathrm{H}_{2} \mathrm{O}$ \\
\hline 3 & $\mathrm{O}\left({ }^{1} \mathrm{P}\right)$ & atomic oxygen (ground state) & 0 & \multicolumn{2}{|c|}{ too reactive } & reacts with $\mathrm{O}_{2}$ \\
\hline 4 & $\mathrm{O}_{2}$ & molecular oxygen & measurements & is emitted, & t important & estimation \\
\hline 5 & NO & nitrogen monoxide & measurements & $<0.0005$ & $<0.0005$ & estimation \\
\hline 6 & $\mathrm{NO}_{2}$ & nitrogen dioxide & measurements & 0.005 & 0.001 & Horii et al., ??? \\
\hline 7 & $\mathrm{NO}_{3}$ & nitrogen trioxide & 1.E+07 & too & & estimation \\
\hline 8 & $\mathrm{~N}_{2} \mathrm{O}_{5}$ & dinitrogen pentoxide & 1.E+07 & 0.02 & 0.008 & aerdynmic limit \\
\hline 9 & $\mathrm{OH}$ & hydroxyl radical & 0 & too & ive & estimation \\
\hline 10 & $\mathrm{HO}_{2}$ & hydroperoxyl radical & 0 & 0.02 & 0.008 & aerdynmic limit \\
\hline 11 & $\mathrm{H}_{2} \mathrm{SO}_{4}$ & sulfuric acid & 0 & 0.02 & 0.008 & aerdynmic limit \\
\hline 12 & $\mathrm{H}_{2} \mathrm{O}_{2}$ & hydrogen peroxide & 0 & 0.02 & 0.008 & aerdynmic limit \\
\hline 13 & $\mathrm{HNO}_{3}$ & nitric acid & 0 & 0.02 & 0.008 & aerdynmic limit \\
\hline 14 & $\mathrm{SO}_{2}$ & sulfur dioxide & measurements & 0.012 & 0.02 & Finkelstein et al., 2000 \\
\hline 15 & $\mathrm{CO}$ & carbon monoxide & measurements & $<0.0002$ & $<0.0002$ & estimation \\
\hline 16 & $\mathrm{CO}_{2}$ & carbon dioxide & measurements & -0.0004 & 0.001 & estimation \\
\hline 17 & $\mathrm{CH}_{4}$ & methane & measurements & $<0.00001$ & $<0.00001$ & estimation \\
\hline 18 & $\mathrm{CH}_{3}$ & methyl radical & 0 & too & & reacts with $\mathrm{O}_{2}$ \\
\hline 19 & $\mathrm{CH}_{3} \mathrm{O}_{2}$ & methylperoxy radical & 0 & 0.02 & 0.008 & aerdynmic limit \\
\hline 20 & $\mathrm{HCHO}$ & formaldehyde & 1. $E+10$ & 0.007 & 0.001 & Wesely 1989 \\
\hline 21 & $\mathrm{C}_{2} \mathrm{H}_{6}$ & ethane & 1. $E+10$ & $<0.0002$ & $<0.0002$ & estimation \\
\hline 22 & $\mathrm{C}_{2} \mathrm{H}_{5} \mathrm{O}_{2}$ & ethylperoxy radical & 0 & 0.02 & 0.008 & analogy to $\mathrm{HO}_{2}$ \\
\hline 23 & $\mathrm{C}_{2} \mathrm{H}_{5} \mathrm{O}$ & ethyl radical & 0 & too & & reacts with $\mathrm{O}_{2}$ \\
\hline 24 & $\mathrm{CH}_{3} \mathrm{CHO}$ & acetaldehyde & 0 & 0.0015 & 0.0015 & Karl et al., 2004 \\
\hline 25 & $\mathrm{CH}_{3} \mathrm{COO}_{2}$ & acetyl peroxy radical & 0 & 0.02 & 0.008 & aerdynmic limit \\
\hline 26 & $\mathrm{CH}_{3} \mathrm{CO}_{3} \mathrm{NO}_{2}$ & peroxyacetylnitrate (PAN) & 0 & 0.01 & 0.005 & Turnipseed et al., 2006 \\
\hline 27 & $\mathrm{nC}_{4} \mathrm{H}_{10}$ & n-butane & 0 & $<0.00001$ & $<0.00001$ & estimation \\
\hline 28 & $\mathrm{C}_{4} \mathrm{H}_{9} \mathrm{O}_{2}$ & tert-butylperoxy radical & 0 & 0.02 & 0.008 & analogy to $\mathrm{HO}_{2}$ \\
\hline 29 & $\mathrm{C}_{4} \mathrm{H}_{9} \mathrm{O}$ & tert-bytoxy radical & 0 & too & & estimation \\
\hline 30 & $\mathrm{CH}_{3} \mathrm{COC}_{2} \mathrm{H}_{5}$ & methy ethyl keton & 0 & 0.0014 & 0.0014 & Karl et al., 2004 \\
\hline 31 & $\mathrm{CH}_{3} \mathrm{COCHO} \mathrm{CH}_{3}$ & peroxy radical & 0 & 0.0014 & 0.0014 & Karl et al., 2004 \\
\hline 32 & $\mathrm{CH}_{3} \mathrm{COCOCH}_{3}$ & venyl acetate & 0 & 0.0014 & 0.0014 & Karl et al., 2004 \\
\hline 33 & $\mathrm{CH}_{2} \mathrm{O}_{2} \mathrm{CH}_{2} \mathrm{OH}$ & 2-hydroxy-1-ethyl peroxy & 0 & 0.0027 & 0.0027 & Karl et al., 2004 \\
\hline 34 & $\mathrm{C}_{2} \mathrm{H}_{4}$ & ethylene & 0 & $<0.00001$ & $<0.00001$ & estimation \\
\hline 35 & $\mathrm{C}_{3} \mathrm{H}_{6}$ & propylene & 0 & $<0.00001$ & $<0.00001$ & estimation \\
\hline 36 & $\mathrm{CH}_{3} \mathrm{CHO}_{2} \mathrm{CH}_{2} \mathrm{OH}$ & 1-hydroxy-2-propyl peroxy & 0 & 0.0027 & 0.0027 & Karl et al., 2004 \\
\hline 37 & $\mathrm{C}_{24} \mathrm{H}_{30}$ & o-xylene & 0 & 0.02 & 0.008 & aerdynmic limit \\
\hline 38 & $\mathrm{CHOCH}=\mathrm{CHCOCH}_{3}$ & peroxy radical & 0 & 0.0014 & 0.0014 & Karl et al., 2004 \\
\hline 39 & $\mathrm{CH}_{3} \mathrm{COCHOH}-\mathrm{CHO}_{2} \mathrm{CHO}$ & peroxy radical & 0 & 0.0014 & 0.0014 & Karl et al., 2004 \\
\hline 40 & $\mathrm{CH}_{3} \mathrm{COCHO}$ & methylglyoxal & 0 & 0.0014 & 0.0014 & Karl et al., 2004 \\
\hline 41 & $\mathrm{CHOCHO}$ & glyoxal & 0 & too & & \\
\hline 42 & $\mathrm{C}_{5} \mathrm{H}_{8}$ & isoprene & $5 . E+09$ & $<0.00001$ & $<0.00001$ & estimation \\
\hline 43 & $\mathrm{OHC}_{5} \mathrm{H}_{8} \mathrm{O}_{2}$ & isoprene peroxy radical & 0 & too & & estimation \\
\hline 44 & $\mathrm{CH}_{3} \mathrm{COCH}=\mathrm{CH}_{2}$ & methacorlein & 0 & $<0.00001$ & $<0.00001$ & estimation \\
\hline 45 & $\mathrm{OHCH}_{3} \mathrm{COCHCH}_{2} \mathrm{O}_{2}$ & methacroten peroxy radical & 0 & 0.0014 & 0.0014 & Karl et al., 2004 \\
\hline 46 & $\mathrm{CH}_{3} \mathrm{OOH}$ & methyl hydroperoxide & 0 & 0.0015 & 0.0015 & Karl et al., 2004 \\
\hline 47 & $\mathrm{CH}_{3} \mathrm{OOH}$ & methyl hydroperoxide & 0 & 0.0015 & 0.0015 & Karl et al., 2004 \\
\hline 48 & $\mathrm{CH}_{3} \mathrm{O}$ & methoxy radical & 0 & too & & reacts with $\mathrm{O}_{2}$ \\
\hline 49 & $\mathrm{SO}_{3}$ & sulfur trioxide & 0 & 0.02 & 0.008 & aerdynmic limit \\
\hline 50 & $\mathrm{HSO}_{3}$ & bisulfite & 0 & 0.02 & 0.008 & aerdynmic limit \\
\hline 51 & $\mathrm{C}_{10} \mathrm{H}_{16}$ & alfa pinene & measurements & netto & sion & \\
\hline 52 & $\mathrm{C}_{10} \mathrm{H}_{16}$ & beta pinene & measurements & netto & sion & \\
\hline 53 & $\mathrm{C}_{10} \mathrm{H}_{16}$ & 3-carene & measurements & netto & sion & \\
\hline 54 & $\mathrm{C}_{10} \mathrm{H}_{16}$ & d-limonene & measurements & netto & sion & \\
\hline 55 & DMS & dimethylsulphat & 0 & 0.02 & 0.008 & aerdynmic limit \\
\hline 56 & $\mathrm{CH}_{3} \mathrm{~S}$ & mercaptomethyl radical & 0 & 0.02 & 0.008 & aerdynmic limit \\
\hline 57 & $\mathrm{CH}_{3} \mathrm{~S}(\mathrm{OH}) \mathrm{CH}_{3}$ & $\mathrm{OH}-\mathrm{DMS}$-adduct & 0 & too & & reacts with $\mathrm{O}_{2}$ \\
\hline 58 & $\mathrm{CH}_{3} \mathrm{SO}$ & & 0 & 0.02 & 0.008 & aerdynmic limit \\
\hline 59 & $\mathrm{CH}_{3} \mathrm{SOO}$ & & 0 & 0.02 & 0.008 & aerdynmic limit \\
\hline 60 & $\mathrm{CH}_{3} \mathrm{SO}_{2}$ & & 0 & 0.02 & 0.008 & aerdynmic limit \\
\hline 61 & $\mathrm{CH}_{3} \mathrm{~S}(\mathrm{O}) \mathrm{O}_{2}$ & & 0 & 0.02 & 0.008 & aerdynmic limit \\
\hline 62 & $\mathrm{CH}_{3} \mathrm{SO}_{3}$ & & 0 & 0.02 & 0.008 & aerdynmic limit \\
\hline 63 & $\mathrm{CH}_{3} \mathrm{~S}(\mathrm{O}){ }_{2} \mathrm{O}_{2}$ & & 0 & 0.02 & 0.008 & aerdynmic limit \\
\hline 64 & $\mathrm{CH}_{3} \mathrm{~S}(\mathrm{O}) \mathrm{O}_{2} \mathrm{NO}_{2}$ & & 0 & 0.01 & 0.005 & like PAN \\
\hline 65 & $\mathrm{CH}_{2} \mathrm{~S}(\mathrm{O})_{2} \mathrm{O}_{2} \mathrm{NO}_{2}$ & & 0 & 0.01 & 0.005 & like PAN \\
\hline 66 & $\mathrm{CH}_{3} \mathrm{SOONO}_{2}$ & & 0 & 0.01 & 0.005 & like PAN \\
\hline 67 & $\mathrm{CH}_{4} \mathrm{O}_{3} \mathrm{~S}$ & methanesulfonic acid (MSA) & 0 & 0.02 & 0.008 & aerdynmic limit \\
\hline 68 & reaction products $f$ & mono-terpene reactions & 0 & 0.02 & 0.008 & aerdynmic limit \\
\hline 69 & reaction products $f$ & m mono-terpene reactions & 0 & 0.02 & 0.008 & aerdynmic limit \\
\hline 70 & $\mathrm{NH}_{3}$ & amonia & measurements & 0.02 & 0.008 & aerdynmic limit \\
\hline
\end{tabular}


The mass balance equation for sulphuric acid is similar:

$$
\begin{aligned}
& \frac{\partial \bar{C}_{\mathrm{H}_{2} \mathrm{SO}_{4}}}{\partial t}+w_{s} \frac{\partial \bar{C}_{\mathrm{H}_{2} \mathrm{SO}_{4}}}{\partial z}= \\
& -\frac{\partial \overline{w^{\prime} C_{\mathrm{H}_{2} \mathrm{SO}_{4}}^{\prime}}}{\partial z}+\bar{P}_{\mathrm{H}_{2} \mathrm{SO}_{4}}-\bar{L}_{\mathrm{H}_{2} \mathrm{SO}_{4}}+\left(\frac{\partial \bar{C}_{\mathrm{H}_{2} S O_{4}}}{\partial t}\right)_{d e p} \\
& \left(\overline{w^{\prime} \mathrm{C}^{\prime}} \mathrm{H}_{2} \mathrm{SO}_{4}\right)_{0}=-v_{d e p, \mathrm{H}_{2} \mathrm{SO}_{4} \bar{C}_{\mathrm{H}_{2} \mathrm{SO}_{4}}}
\end{aligned}
$$

Here, the loss term $L_{\mathrm{H}_{2} \mathrm{SO}_{4}}$ represents the amount of $\mathrm{H}_{2} \mathrm{SO}_{4}$ condensing onto particles and participating in nucleation mechanisms. The turbulent fluxes of the chemical species were parameterised using K-theory, whereas the eddy diffusivity for the scalars (e.g., heat) was applied.

Second-order reaction rate coefficients are calculated from Arrhenius-type expressions:

$k(T)=A * \exp (-E / R T)$

where the corresponding values for $A$ and $E / T$ are listed in Appendix A. Third-order reactions rate coefficients are calculated using a Troe formulation:

$k(T)=\frac{k_{o}[M]}{\left(1+\frac{k_{o}[M]}{k_{\infty}}\right)} * F c^{\left(1 /\left[1+\left[\log \left(\frac{k_{o}[M]}{k_{\infty}}\right)\right]^{2}\right]\right)}$

$k_{o}(T)=k_{o}^{300} *(T / 300)^{-n} \exp (-E / R T)$

$k_{\infty}(T)=k_{o}^{300} *(T / 300)^{-m} \exp (-E / R T)$

These are listed in Appendix B. Photo-dissociation rate coefficients are based largely on the work of Finlayson-Pitts and Pitts 1986 and are calculated according to equation

$k_{A}=\sum_{\lambda=280}^{700} \bar{\sigma}_{s}(\lambda, T) * \bar{\phi}(\lambda) * \bar{I}(\lambda) * \Delta \lambda$

where the absorption cross-sections, $\sigma_{s}$, and quantum yields, $\phi$, are modified such that $\Delta \lambda=5 \mathrm{~nm}$ (Appendix C) (Atkinson and Lloyd, 1984; Atkinson et al., 1989; Baulch et al., 1982). The solar actinic flux, $I$, is calculated using latitude, longitude and day of the year to predict top of the atmosphere short wavelength downward irradiance for every time-step. The values are further corrected by short wavelength measurements from Hyytiälä at noon to reflect the real daily irradiance input (depending on the aerosol optical thickness) and compared with measured spectral radiation measurements of the selected day. The differential equations were solved using the NAG-library FORTRAN routine D02EJF.

\subsection{Aerosol dynamics}

The aerosol dynamics are solved by the size-segregated aerosol model, UHMA (University of Helsinki Multicomponent Aerosol model). A detailed description of the model has been recently published by Korhonen et al. (2004). The model includes the major aerosol microphysical processes for a clear-sky atmosphere. It focuses on new particle formation and growth; thus, it incorporates both particle coagulation and multicomponent condensation. It considers a revised treatment of condensation flux onto free molecular regime particles, including activation of nano-sized clusters by organic vapours (Nano-Köhler theory), and recent parameterisations for binary $\mathrm{H}_{2} \mathrm{SO}_{4}-\mathrm{H}_{2} \mathrm{O}$, ternary $\mathrm{H}_{2} \mathrm{SO}_{4}-\mathrm{NH}_{3}$ $\mathrm{H}_{2} \mathrm{O}$ and kinetic nucleation $\mathrm{H}_{2} \mathrm{SO}_{4}-\mathrm{H}_{2} \mathrm{SO}_{4}$. Particle dry deposition is also calculated according to Rannik et al. (2003). In order to account for deposition of newly formed particles, we have extrapolated the Rannik et al. (2003) results to particle sizes less than $10 \mathrm{~nm}$.

The representation of particle size distribution applied in this version of UHMA can be chosen from two methods: the fixed sectional and the moving centre approach. Sensitivity studies and a detailed discussion of the advantages and disadvantages of both methods can be found in Korhonen et al. (2004). In the present study we have used the fixed sectional approach with 40 size bins.

The simulated aerosol phase chemical components consist of sulphuric acid, water-soluble organic compounds, and an arbitrary number of insoluble constituents representing, e.g., mineral dust, water-insoluble organics, and black carbon. Out of these, sulphuric acid and the organic compounds are treated as condensable species. The condensation flux of these vapours onto the particles depends on the properties of the vapour, the particle composition, and the shape of the particle distribution. The onset of low or semi-volatile organic vapour condensation onto the nano-sized inorganic clusters is determined by Nano-Köhler theory, which describes the thermodynamic equilibrium between an inorganic cluster, water, and a water soluble organic compound. For further details of the thermodynamic model, we refer the reader to Kulmala et al. (2004b). The particle water and ammonia content, on the other hand, is determined at every time step by equilibration of gaseous water and ammonia with the particulate sulphate and water-soluble organic fraction.

The model incorporates three schemes of homogeneous new particle formation: (a) binary $\mathrm{H}_{2} \mathrm{SO}_{4}-\mathrm{H}_{2} \mathrm{O}$ (Kulmala et al., 1998), (b) ternary $\mathrm{H}_{2} \mathrm{SO}_{4}-\mathrm{H}_{2} \mathrm{O}-\mathrm{NH}_{3}$ (Napari et al., 2002), and (c) kinetic limited nucleation. If kinetic nucleation is switched off the critical value of ammonia is set to $0.1 \mathrm{pptv}$ due to the lower validity limit of the ternary parameterisation. When ammonia concentrations are below this critical level, ternary nucleation rates are very small, such that this assumption does not introduce significant errors in the model simulations. During this work we tested all three nucleation codes and used kinetically limited nucleation as the most accurate mechanism.

The coagulation kernel used in the model accounts only for Brownian diffusion. For submicron particles, coagulation tends to dominate over other mechanisms. The turbulent fluxes of the particle number concentration were calculated 
Table 2. Physical properties of sulphuric acid and organic vapour I and II (see Sect. 3).

\begin{tabular}{lllll}
\hline Density & {$\left[\mathrm{kg} \mathrm{m}^{-3}\right]$} & 1183 & 1400 & 1400 \\
Molar mass & {$\left[\mathrm{g} \mathrm{mol}^{-1}\right] 98.08$} & 150 & 150 & \\
Saturation concentration above flat surface & {$\left[\mathrm{H} \mathrm{m}^{-3}\right] 0.0 \mathrm{E}+00$} & $1.0 \mathrm{E}+12$ & $1.0 \mathrm{E}+12$ & \\
Surface tension & {$\left[\mathrm{N} \mathrm{m}^{-1}\right] 5.5 \mathrm{E}-02$} & $4.0 \mathrm{E}-02$ & $4.0 \mathrm{E}-02$ & \\
Diffusion volume & & 51.96 & 51.96 & 51.96 \\
Mass accomodation coefficient & & 1 & 1 & 1 \\
\hline
\end{tabular}

using the eddy diffusion coefficient for heat. These values are further used by the Runge-Kutta time scheme to predict new number concentrations and volumes in all size bins at each level.

\section{Model initialisation}

The initialisation of the meteorological data depends on the availability of vertical measurements. For Hyytiäla, soundings were used from Jokioinen, a monitoring station of the Finnish Meteorological Institute located about $100 \mathrm{~km}$ southwest of Hyytiälä. Temperatures at $1 \mathrm{~m}, 0 \mathrm{~m}$ and at $1 \mathrm{~m}$ depth within the soil were from measurements at the SMEAR II station in Hyytiälä. A detailed description of the station and instrumentation can be found in Kulmala et al., 2001 and under http://www.honeybee.helsinki.fi/smear/.

The initial gas concentrations of most species - especially the organic reaction products - were set to zero during the night at the start of the model run (see Table 1). For several other gases like $\mathrm{CO}, \mathrm{NO}, \mathrm{NO}_{\mathrm{x}}$ or Ozone, measurements from the SMEAR II station were used. However, because of the lag of vertical profiles during night time, we assumed a constant distribution throughout the residual layer for all gases except the monoterpenes, $\mathrm{NH}_{3}$ and $\mathrm{SO}_{2}$. The monoterpene concentrations were measured diurnally with an assumed vertical gradient of

$\frac{d Q(z)}{d z}=Q(z)\left(1-\frac{z}{8000}\right)$

in agreement with earlier measured profiles (Boy et al., 2004).

Sulphur dioxide and ammonia are two important species for the ternary nucleation mechanism. Sulphur dioxide is produced by fossil-fuel combustion, industry and volcanoes and reaches the Hyytiälä site via horizontal advection. $\mathrm{SO}_{2}$ concentrations were initialised using the daily measured profiles at ground level with the same vertical distribution as the monoterpenes for all model runs to contribute for emissions from some towns nearby. In the case of $\mathrm{NH}_{3}$, both deposition and emission fluxes are possible, depending on the compensation point for the surface vegetation (Langford and Fehsenfeld, 1992). However, currently there is no emission/deposition module for ammonia in MALTE. Therefore, we have used the measured diurnal surface concentrations and assumed a similar vertical gradient as for the monoterpenes.

The initial aerosol concentrations and size distributions at the surface were based on DMPS (Differential Mobility Particle Sizer) and APS (Aerodynamic Particle Sizer) measurements from the SMEAR II station. We assume the same vertical gradient as for the monoterpenes to initialise the vertical aerosol distribution, however, we also account for aerosol deposition processes.

Currently there is a considerable lack of knowledge concerning the atmospheric oxidation of complex organic molecules such as monoterpenes. The identities of the endproducts, their reaction yields and their physical and chemical properties are not well-characterised. Therefore, in MALTE we have assumed a yield from monoterpene oxidation (Appendix A, Reactions 69-80) of 0.05 for all reaction products (Organic vapour I) capable of condensing on nanosized inorganic clusters (as determined using Nano-Köhler theory) and a yield of 0.05 for all products (Organic vapour II) capable of being involved in the general condensation mechanism. These two yield values were found to give the best agreement for particle growth and size distribution with the measured values for the selected days. Boy et al. (2003) previously used a yield of 0.03 for the reaction products of the monoterpenes to calculate the contribution from the organics to the growth of the nucleation mode particles based on simulation of the MCM 2.0 (Master Chemical Mechanism, Jenkin et al., 2000). However, this lower value resulted in overestimating the number concentrations of small particles and underestimating the concentrations of organics needed to grow the newly-formed clusters compared to the measured distributions. The physical properties for sulphuric acid and the "pseudo" organic vapours I and II used in the condensation schemes are listed in Table 2. The simplified assumptions to calculate the amount of condensable vapours with measured monoterpenes concentrations reflects only the quantitative role of organic vapours in the particle formation processes. Further improvements in the chemical module and knowledge about emissions of higher terpenes like the sesquiterpenes will in the future give more qualitative information about the real organic species.

The formation of new clusters was calculated inside the UHMA code by binary, ternary and kinetic nucleation with an average ammonia concentration of 24 pptv based on the 

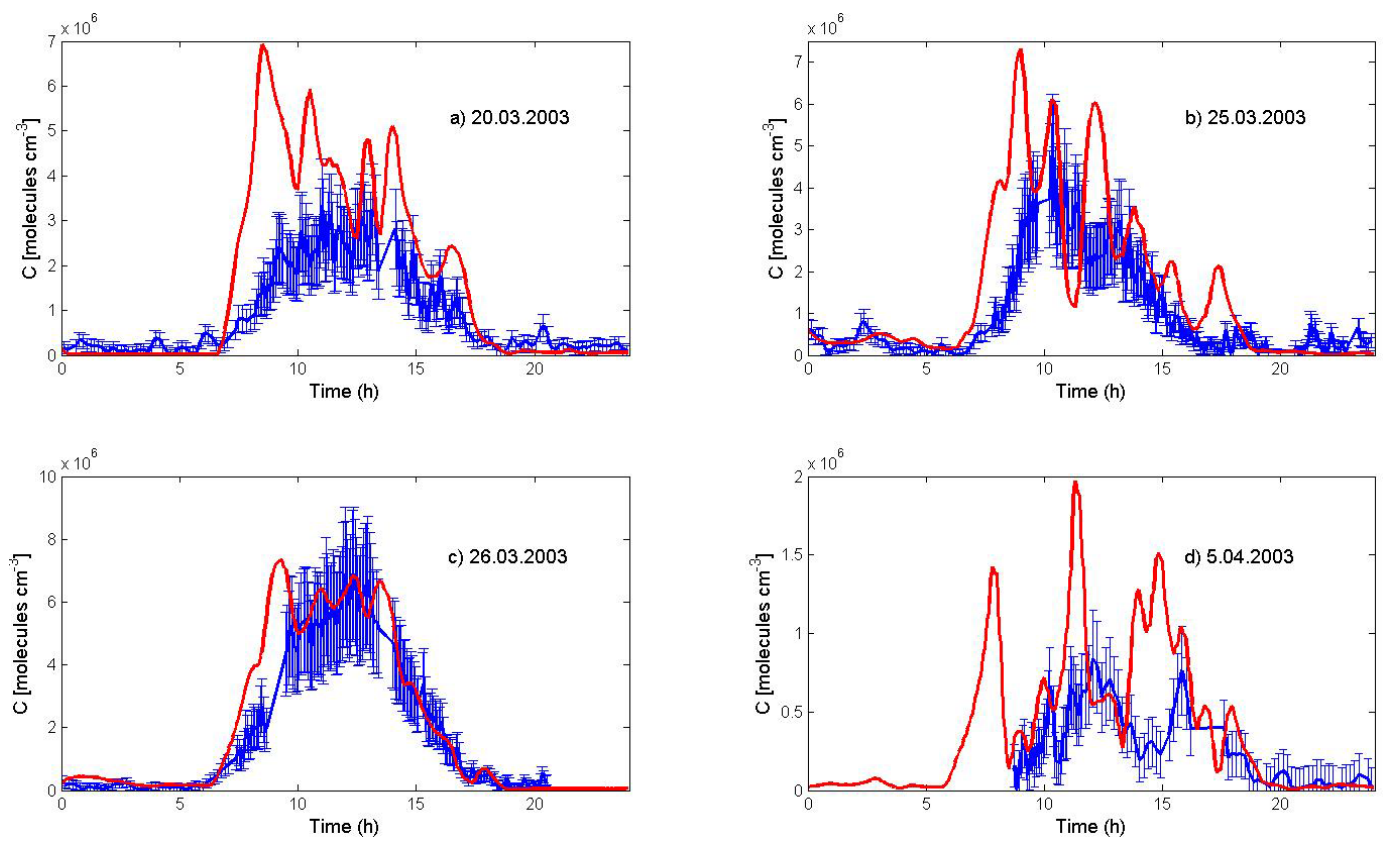

Fig. 2. Measured and modelled sulphuric acid concentrations for all selected days. Red lines denote modelled values; blue lines represent measurements with uncertainties.

measured values. Model simulations using this amount of ammonia resulted for the ternary code in cluster formation rates that were by a factor of 10 higher compared to measured particle size distributions, whereas binary nucleation always strongly underestimated the amount of newly formed particles. Kinetic nucleation was calculated by

$J=K *\left[\mathrm{H}_{2} \mathrm{SO}_{4}\right]^{2}$

with $K$ as the kinetic coefficient, containing the details of the nucleation process, specially the probability that a collision of two molecules results in the formation of a stable critical cluster. Varying this factor in conjunction with the production yield of the condensable organics indicated that a value of $K=1 \times 10^{-12} \mathrm{~cm}^{3} \mathrm{~s}^{-1}$ best reproduced the observed values. A value similar to the results published recently by Sihto and co-authors (2005 - mean $K=0.6 \times 10^{-12} \mathrm{~cm}^{3} \mathrm{~s}^{-1}$ ).

This approach is also similar to that of Weber et al. (1996), who empirically derived a nucleation rate based on field measurements. Assuming a steady-state cluster distribution, the upper limit for the new particle formation rate is the rate at which $\mathrm{H}_{2} \mathrm{SO}_{4}$ collides with itself, $\left.\beta \mathrm{H}_{2} \mathrm{SO}_{4}\right]^{2}$, where the collision frequency function $\beta$ was reported to be about $3 \times 10^{-10} \mathrm{~cm}^{3} \mathrm{~s}^{-1}$. With consideration of the effect of stabilising species such as $\mathrm{NH}_{3}$ on clusters containing one or more $\mathrm{H}_{2} \mathrm{SO}_{4}$ molecules and $\mathrm{H}_{2} \mathrm{O}$, the steady state rate of particle formation in the absence of cluster scavenging by pre-existing particles can be parameterised as follows:

$J_{\text {Weber }}=\beta \gamma\left[\mathrm{H}_{2} \mathrm{SO}_{4}\right]^{2}$ with $\beta=3 \times 10^{-10} \mathrm{~cm}^{3} \mathrm{~s}^{-1}$ and $\gamma=0.001-0.003$. Considering the usual uncertainties of commonly used nucleation parameterisations, the pre-factor $\beta \gamma=(3-9) \times 10^{-13} \mathrm{~cm}^{3} \mathrm{~s}^{-1}$ in the approach of Weber et al. (1996) is only marginal smaller than that used in the present approach.

Currently, the processes governing the formation of clusters and the species involved is an unresolved question and will require further study to elucidate the exact mechanisms. However, our results suggest that kinetic nucleation could be the possible nucleation mechanism for the formation of clusters as suggested recently by Kulmala et al. (2005). The constant kinetic coefficient used here may be a function of different parameters, e.g., temperature or humidity, and could to some extend also depend on the availability of certain organic reaction products.

The days we have chosen to test MALTE took place during an intensive field campaign of the EU QUEST (Quantification of Aerosol Nucleation in the European Boundary layer) project, which was conducted in Hyytiälä, Finland in March-April 2003. We have selected three days with different aerosol loadings in which new particle formation was observed (20, 25 and 26 March), and one non-event day (4 April). For all days the simulation time was $24 \mathrm{~h}$ starting at 00:00 EET (winter time).

\section{Results}

Figure 2a-d gives the measured (Boy et al., 2005; Fiedler et al., 2005) and calculated sulphuric acid concentrations for all 

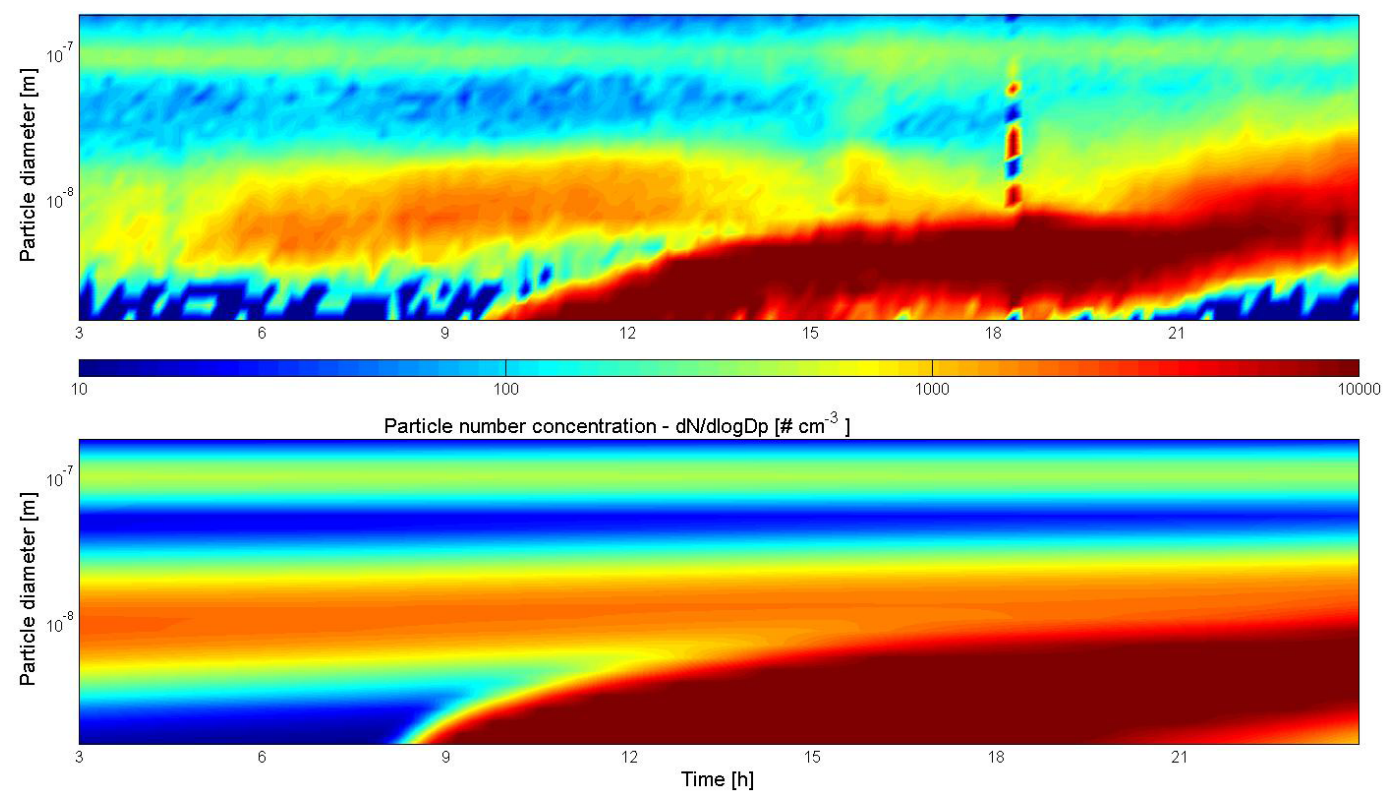

Fig. 3. Measured (upper plot) and modelled (lower plot) particle size distributions for the 20 March 2003.

selected days at the surface. The model tends to overestimate $\mathrm{H}_{2} \mathrm{SO}_{4}$ concentrations in the first hour after sunrise. This effect could result from the fact that the measurements were performed in a clearing within the forest which decreased the actinic flux at sunrise under stable atmospheric conditions. The large $\mathrm{H}_{2} \mathrm{SO}_{4}$ fluctuations during simulation day 1, 2 and 4 (Figs. 2a, b and d) reflect the sensitivity of the model against the fluctuations in the measured sulphur dioxide profile. On these days, $\mathrm{SO}_{2}$ concentrations were always below $0.5 \mathrm{ppb}$ which is near the detection limit of the instrument. However, the general patterns of the modelled $\mathrm{H}_{2} \mathrm{SO}_{4}$ concentrations agree to a large extent with the measured data on the event days. On the 4 April the model over-predicts the concentration at some times by approximately a factor of $2-3$. One explanation for this high concentration could be the fluctuations in the sulphur dioxide concentrations and/or the existence of fog droplets with diameters above $20 \mu \mathrm{m}$, the upper detection limit of the APS system. The relative humidity on this cloudy day showed a converse pattern compared to the other days with values between 90 and $100 \%$, which then decreased around 17.00, the time when the measured and simulated sulphuric acid concentrations start to agree. In general the model seems to predict sulphuric acid concentrations quite well and future refinements of the chemical reaction mechanism and the condensation sink will likely further increase the accuracy for this specie.

The kinetic nucleation used $\mathrm{H}_{2} \mathrm{SO}_{4}$ concentrations to produce a number of newly-formed clusters. Whether these newly-formed clusters will survive to grow (by condensation of vapours) into a larger particle or coagulate onto an existing aerosol is strongly dependent on the amount of ex- isting aerosols or the condensation sink. During this work, the input aerosol background was the measured aerosol distribution during the night which gave the best correlation to the aerosol loading for the corresponding day. However, although new particle formation has often been observed over distances ranging from approximately $50 \mathrm{~km}$ to the synoptic scale $(>1000 \mathrm{~km}$ ) (Stratmann et al., 2003; Komppula et al., 2003), the particle distribution and number concentration will be influenced to some extent by horizontal advection during the day. This effect will not be reproduced by a one dimensional model and some uncertainties concerning the formation and growth of particles will always result from the diurnal pattern of the background aerosols.

The 20 March (Fig. 3) shows a typical example of the diurnal aerosol pattern explained above. Although the wind direction was continuously from the North throughout the day, the aerosol background concentration shows a minimum around 4.00 and a second decrease around noon. For this day we picked the aerosol loading for the model run at around 8.00 , just prior to the onset of new particle formation. MALTE starts to produce new particles at exactly the same time as the observations and with nearly the same total particle number concentration (Fig. 4a). In the early afternoon the newly formed particles have grown to between 5 to $10 \mathrm{~nm}$ in size and by around 21:00 the new particles in the smallest detectable size range have decreased to near zero. The model maintains the higher background aerosol loading from the morning through the afternoon. For this reason, the condensable vapour available for the growth of the new formed particles is less than the amount available in the real atmosphere. During this day, monoterpene concentrations 

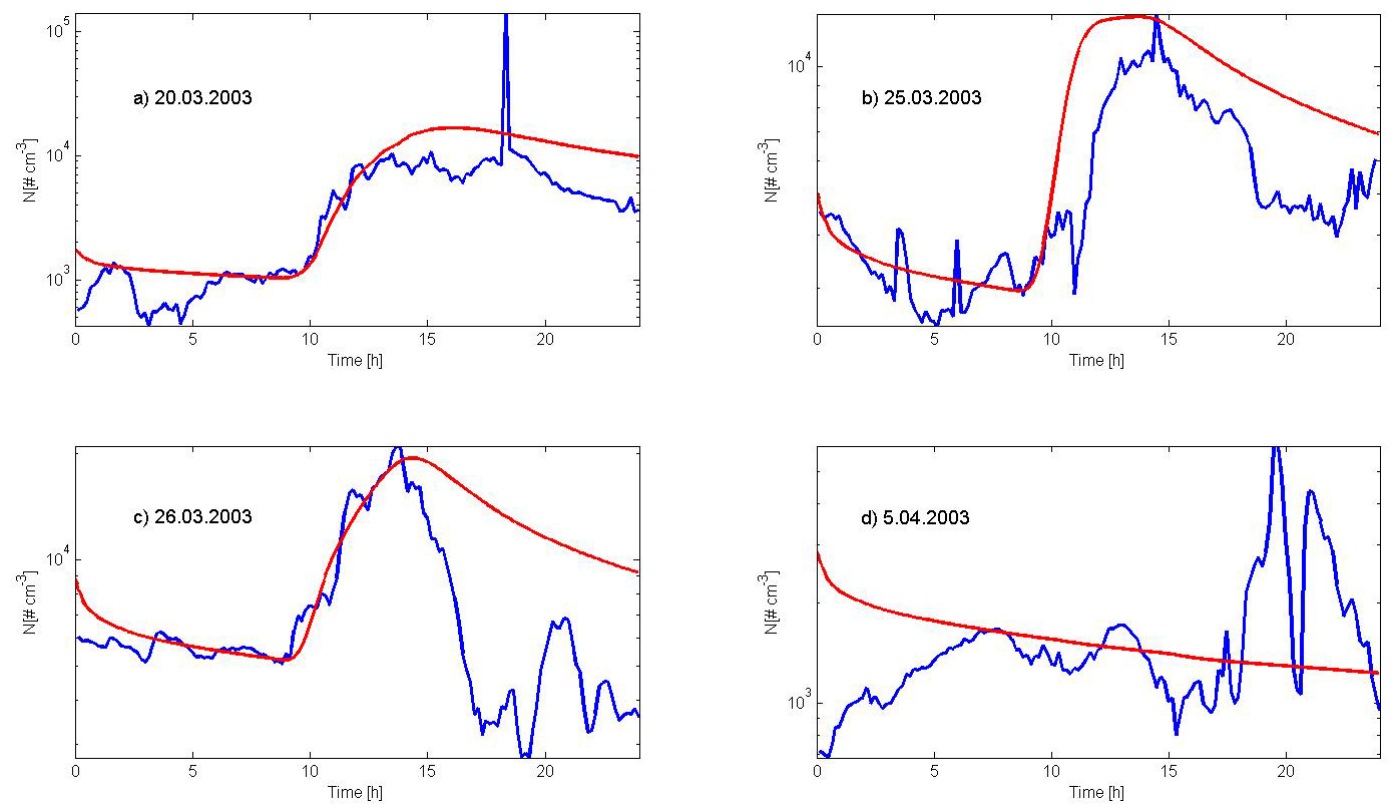

Fig. 4. Measured and modelled total particle number concentration for all selected days. Red lines denote modelled values; blue lines represent measurements.

increased from below detection limit up to $156 \mathrm{ppt}$ between 21:00 and 23:00. This is likely to result in a high amount of condensable vapours leading to a strong growth rate at the end of this day. The model shows a similar behaviour during the evening hours with smaller growth rates, but lacks sufficient night-time chemistry and concentrations of other organic precursors (e.g. sesquiterpenes) to reproduce the existence of these high amounts of condensable vapours at this time of the day.

The 25 March features the same basic structure with a smaller particle decrease around noon and a higher background aerosol concentration (Figs. 5 and 4b). MALTE predicts the onset of the new particle formation on this day as well and stops around the same time as the measured particle burst ends. The decrease in the measured Aitken mode concentration after 12:00 occurred concurrently with the continuous growth of newly formed particles with a nearly constant growth rate which persisted throughout the afternoon. However, this "dilution" is most likely a horizontal advection effect and, similar to the first day, provides a higher amount of condensable organic species relative to the model which maintains the higher background aerosol concentration.

A more constant pattern of aerosol size distribution for the existing particles was observed during our last selected event day, the 26 March (Figs. 6 and 4c). On this day, aerosol number concentration decreased after the evolution of the mixed layer around 09:00 and showed a small fluctuation in the late afternoon. Modelled and measured aerosol size distributions, including the particle formation burst, and the total aerosol number concentrations showed a high degree of correlation. An interesting aspect on this day is that both measured and modelled aerosol distributions show a similar two mode structure during the afternoon. In contrast to the earlier days where measurements showed a decreasing background aerosol concentrations and a merging unique Aitken mode distribution in the late afternoon, the nucleation mode and the Aitken mode aerosols are both visible in the measurements on this day in agreement with the model.

To test our model for days with clean air masses from north but with no observed particle formation, we have selected the 5 April (Figs. 7 and 4c). This day showed similar background aerosol concentrations as the 20 March, but cloudy conditions during the entire day decreased the solar irradiance to less than half of that observed on event days. This tends to explain the low sulphuric acid concentrations observed on this day (Fig. 2) as photochemical production was suppressed. The observed high aerosol concentrations around sunset were likely due to advection of polluted air over the site and not local particle formation as evidenced by the lack of very small particles during this time. Therefore, it appears that our model can satisfactorily predict both the onset and the amount of newly-formed particles on these days within a reasonable degree of uncertainty caused by fluctuations in the background aerosol concentration.

In our model simulations, new particles grow by condensation of both sulphuric acid and organic vapours (primarily organic acids, such as di-carboxylic acids). Boy et al. (2003) previously estimated the contribution of sulphuric acid molecules to the particle growth in the nucleation mode to be between $8-50 \%$. In Fig. 8 we have plotted the ratio 

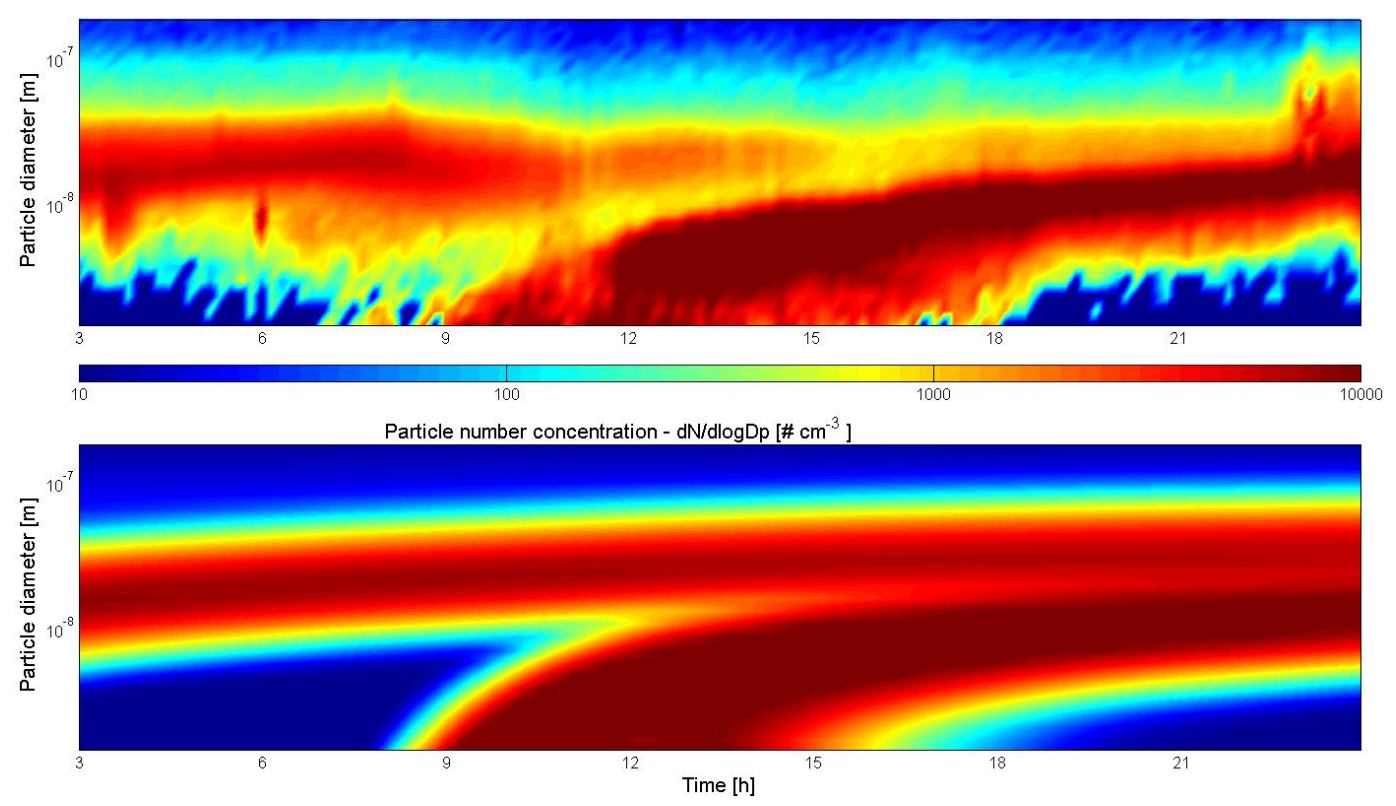

Fig. 5. Measured (upper plot) and modelled (lower plot) particle size distributions for the 25 March 2003.
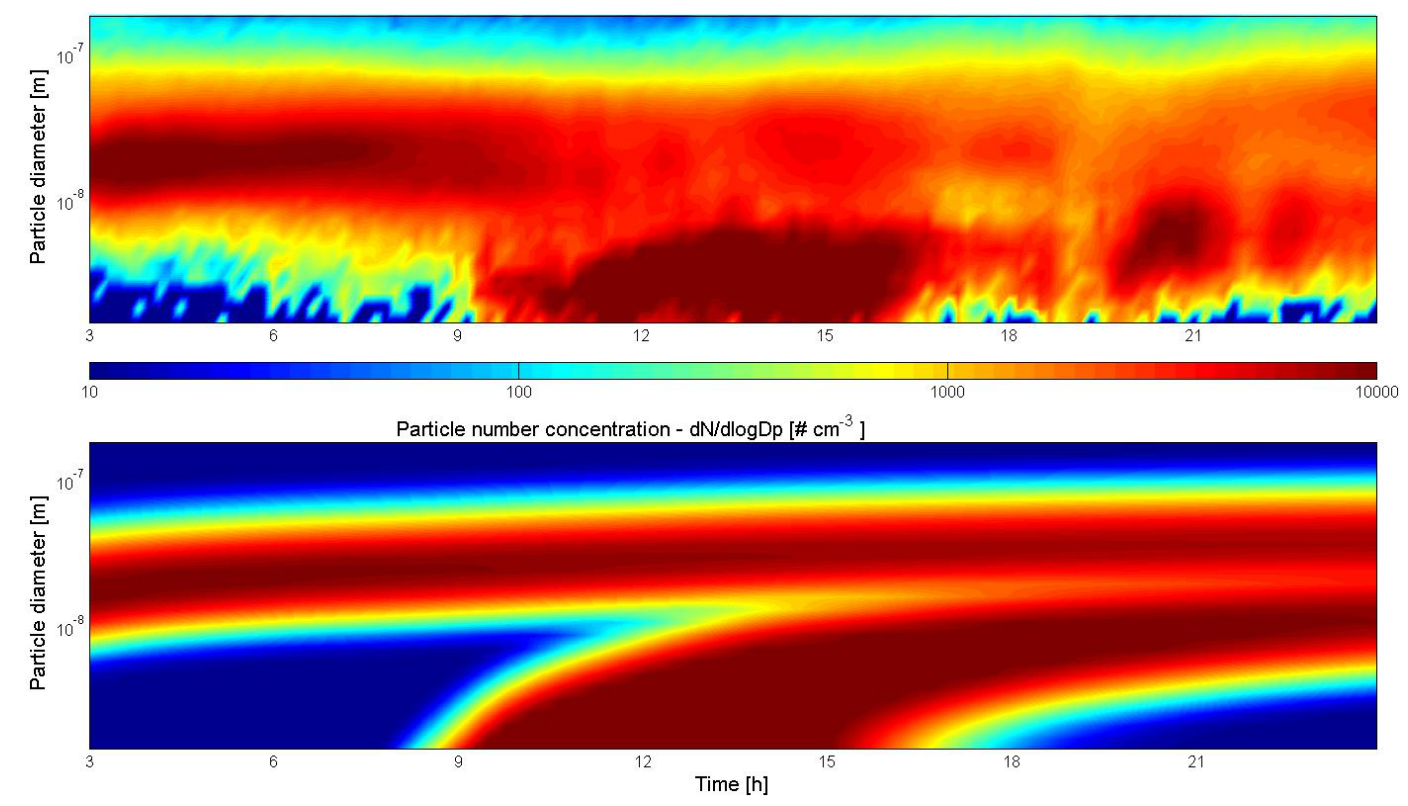

Fig. 6. Measured (upper plot) and modelled (lower plot) particle size distributions for the 26 March 2003.

of the particle growth rate via $\mathrm{H}_{2} \mathrm{SO}_{4}\left(\mathrm{GR}\left[\mathrm{H}_{2} \mathrm{SO}_{4}\right]\right)$ to the growth rate due to organic vapours (GR[Organics]) versus either particle diameter (Fig. 8a) or time of day (Fig. 8b) for the four selected days. Under the conditions studied here, the growth rate for particles with diameters below about 2$7 \mathrm{~nm}$ is primarily controlled by sulphuric acid. Similar results were published by Wehner and co-authors (2005) recently. They calculated that new particles needed to reach a size range between about $7-20 \mathrm{~nm}$ before it becomes appar- ent that organic (semi-volatile) vapours can contribute significantly to the growth rate $\left.\left(\mathrm{GR}\left[\mathrm{H}_{2} \mathrm{SO}_{4}\right] / \mathrm{GR}[\mathrm{Organics}]\right) \leq 2\right)$. However, their observations were from a more urban site in Germany with up to twice as much $\mathrm{H}_{2} \mathrm{SO}_{4}$. In the present study at the more rural South-Central Finland site, this size range seems to be shifted to smaller diameters. After the particles reached this transitional size, the contribution of sulphuric acid to the particle growth rate typically dropped to around $10-30 \%$. The 20 March diverged from this trend, 

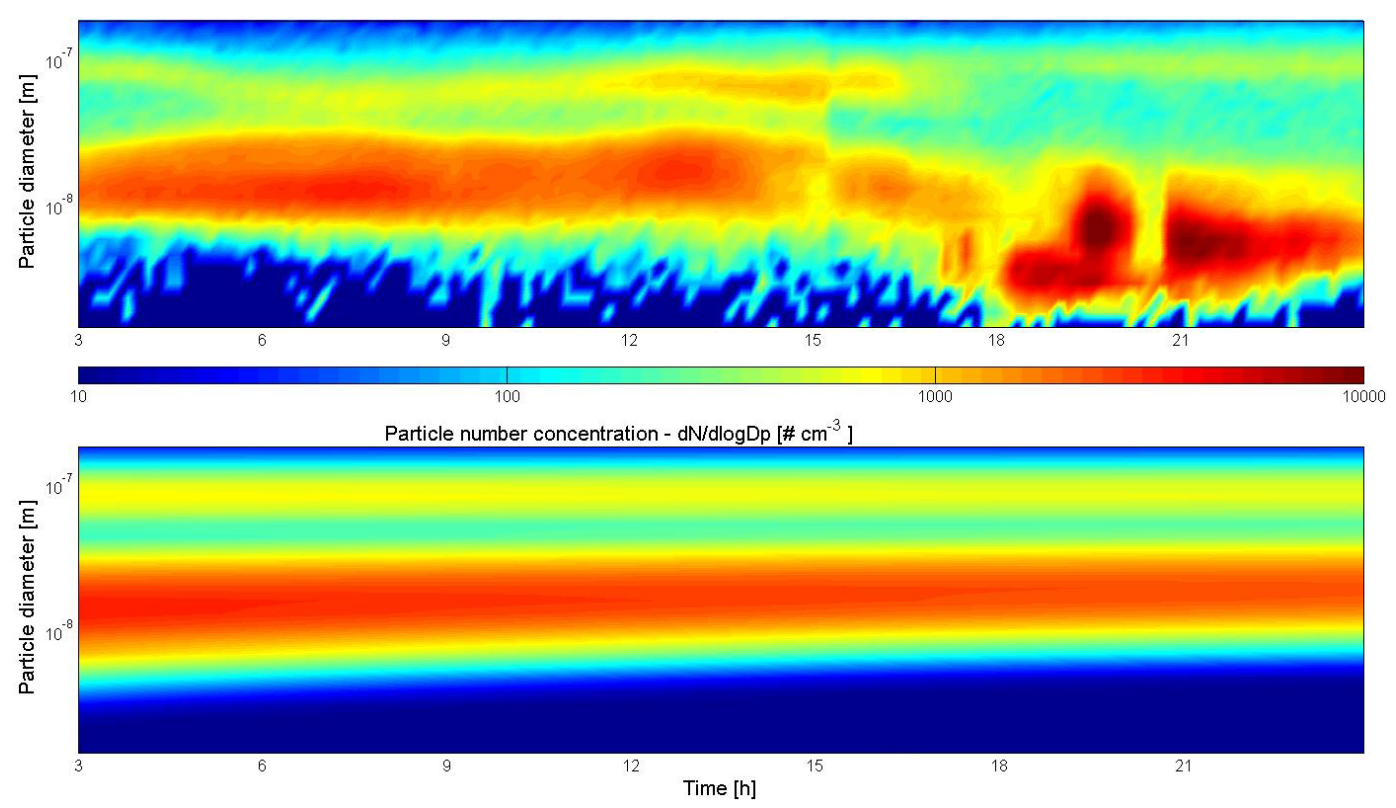

Fig. 7. Measured (upper plot) and modelled (lower plot) particle size distributions for the 4 April 2003.
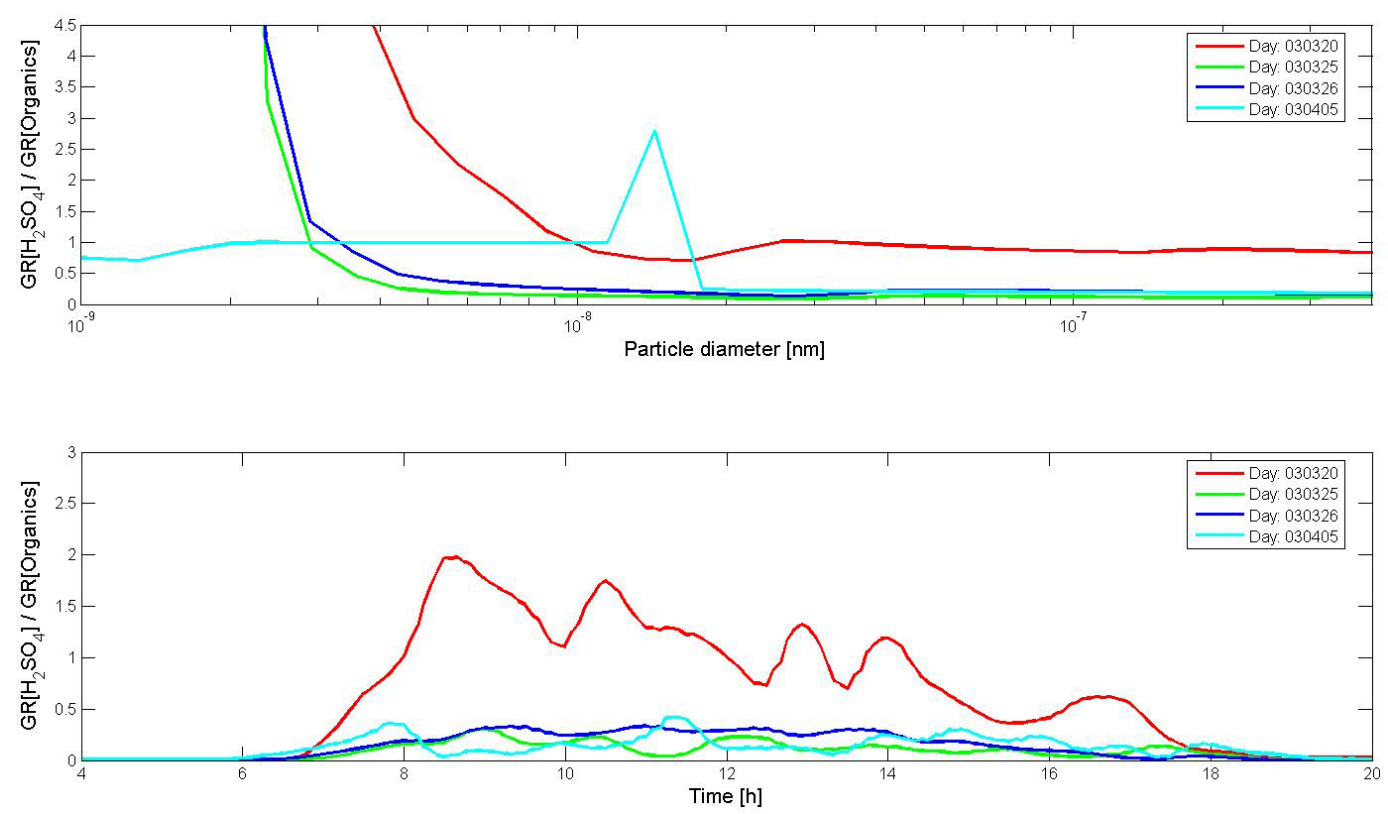

Fig. 8. Ratio of the growth rate by sulphuric acid to that by organic vapours against the particle diameter (a) and time of the day (b).

indicating that sulphuric acid equals the growth compared to the organic vapour over the entire size spectrum above $7 \mathrm{~nm}$. This day was $5-10^{\circ} \mathrm{C}$ cooler $\left(T_{\max }=-5^{\circ} \mathrm{C}\right)$ than the other case days and observed monoterpene concentrations were below the detection limit until after 21:00. Therefore, contribution to the particle growth rate by organic vapours was suppressed.

The initial distributions of the aerosol background concentrations at the model start were based on DMPS and APS ground measurements with a vertical gradient (details see Sect. 3). Figures 9a and $b$ show the vertical daily evolution of particle number concentration in 2 different size ranges ( 1 to 3 and 3 to $6 \mathrm{~nm}$ ) for the 26 March. The simulations of the newly formed clusters with diameters $<3 \mathrm{~nm}$ indicates two maxima in the morning and around noon at ground level. Later, these clusters have grown to the detectable size range of 3 to $6 \mathrm{~nm}$. The results showed in Fig. $9 \mathrm{~b}$ agree with measured vertical profiles between 11:21 and 11:31 for the same 

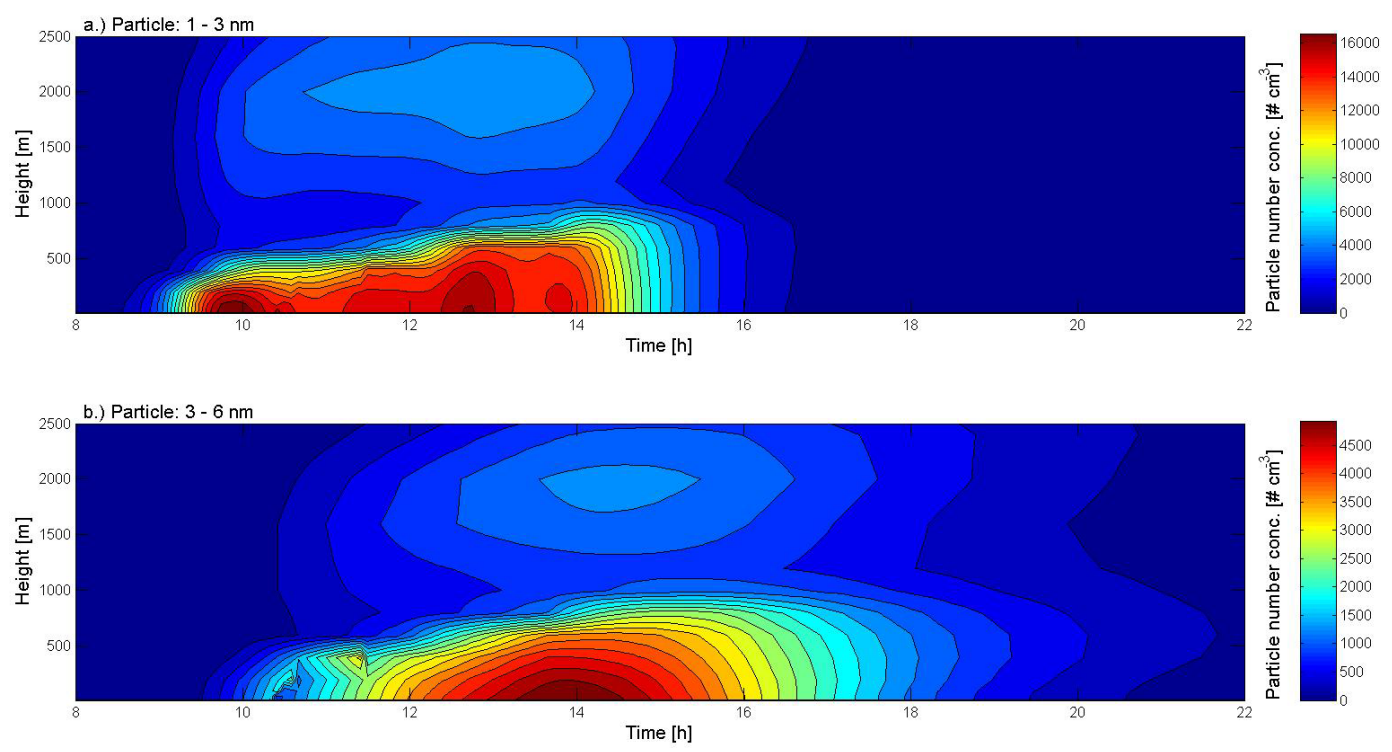

Fig. 9. Vertical daily evolution of particle number concentrations in two different size ranges for the 26 March 2003.

day reported by O'Dowd et al. (2005), in which the authors reported high number concentrations of particles between 3 to $6 \mathrm{~nm}$ from about $100 \mathrm{~m}$ (lowest flight height) up to $500 \mathrm{~m}$ and a decrease above.

\section{Summary and conclusions}

During this study we used a one-dimensional model (MALTE) with a chemical and aerosol module to calculate the amount of newly-formed particles in the mixed layer. In the current model, kinetic nucleation of $\mathrm{H}_{2} \mathrm{SO}_{4}$ was considered to be the primary mechanism for the formation of new particles. It was found that the predicted particle size distributions were in agreement with the measurements by using a value of $1 \times 10^{-12} \mathrm{~cm}^{3} \mathrm{~s}^{-1}$ for the kinetic coefficient. This parameter includes the probability that a collision of two molecules results in the formation of a stable critical cluster, as well as all other important details concerning the nucleation process like, e.g., temperature, humidity, or organic vapours influences. Future work has to clear up the exact equation for the kinetic coefficient.

The concentrations of the condensing organic species were calculated from the reaction products of the monoterpenes with $\mathrm{OH}, \mathrm{O}_{3}$ and $\mathrm{NO}_{3}$ assuming an aerosol yield of 0.05 for the condensation upon the nano-sized inorganic clusters by Nano-Köhler theory and a yield of 0.05 for the main condensation scheme, respectively. Both of these estimates are based on optimising the model runs to reproduce observed values. Due to uncertainties in the atmospheric degradation of monoterpenes and the identities and properties of the condensing organics, this is the only possible strategy at present.

For four selected days ( 3 days with new particle formation and one day without) our model predicted the on- and offset of new particle formation as well as the total aerosol number concentrations that were in good agreement with the observations. We further compared the predicted and measured $\mathrm{H}_{2} \mathrm{SO}_{4}$ concentrations for all days and found satisfactory agreement on all event days. On the non-event day, the modelled sulphuric acid concentrations were partly a factor of 2-3 higher than the measured $\mathrm{H}_{2} \mathrm{SO}_{4}$. One possible explanation could be a high uptake of $\mathrm{H}_{2} \mathrm{SO}_{4}$ by existing fog droplets. The simulation results further indicated that at a certain transitional particle diameter $(2-7 \mathrm{~nm})$, organic molecules can begin to contribute significantly to the growth rate compared to sulphuric acid. At even larger particle sizes, organic molecules can dominate the growth rate on days with significant monoterpene concentrations.

Even with the large uncertainty in nucleation mechanisms and the chemistry (properties of condensable organics) MALTE is capable of adequately reproducing aerosol observations at this early stage in its development. Under real atmospheric situations the model can produce realistic amount of clusters that are necessary to explain observed nucleation events. However, at this point we cannot exclude the possibility of other nucleation mechanism like "ion-induced" or "organic-sulfuric acid" nucleation which are not included in the model. As progress is made in both the field of aerosol nucleation theory and the photochemical degradation of organic terpenoid compound, we hope to incorporate these into future versions of MALTE. Further improvements include the addition of a module for estimating the net emission of gases and aerosols from terrestrial ecosystems to the atmosphere (MEGAN, paper submitted to ACP - already implemented). This should help refine the estimated emission of terpenoid compounds which are likely to oxidise and produce condensable products. We also plan to extend our chemical 
module to move from using "pseudo" organics to real condensable species. In parallel to these improvements, we plan to include a new parameterisation for ion-induced nucleation (Lovejoy et al., 2004) to investigate the contribution of this nucleation mechanism under different atmospheric situations.

\section{Appendix A}

Reactions rate and rate coefficients for second order reactions ( 1 = Atkinson et al., 1992; 2 = De More et al., 1997; 3 = Simpson, 1992; 4 = Atkinson et al., 1989; 5 = Atkinson et al., 1984; 6 = Janson, 1992; 7 = Atkinson et al., 1986; 8 = Atkinson et al., 1990; 9 = Saltelli and Hjorth, 1995).

\begin{tabular}{|c|c|c|c|c|c|c|}
\hline \multirow[t]{2}{*}{$\mathrm{Nr}$. } & \multirow[t]{2}{*}{ Reactant } & & \multirow[t]{2}{*}{ Reaction products } & \multicolumn{2}{|c|}{ Reaction rate } & \multirow[t]{2}{*}{ Ret } \\
\hline & & & & A-factor & $\mathrm{E} / \mathrm{R}$ & \\
\hline 1 & $\mathrm{O}\left({ }^{1} \mathrm{D}\right)+\mathrm{M}$ & $\rightarrow$ & $\mathrm{O}\left({ }^{3} \mathrm{P}\right)+(\mathrm{M})$ & $3.20 \mathrm{E}-11$ & 67 & 1 \\
\hline 2 & $\mathrm{O}\left({ }^{1} \mathrm{D}\right)+\mathrm{H}_{2} \mathrm{O}$ & $\rightarrow$ & $2 \mathrm{OH}$ & $2.20 \mathrm{E}-10$ & 0 & 1 \\
\hline 3 & $\mathrm{NO}+\mathrm{O}_{3}$ & $\rightarrow$ & $\mathrm{NO}_{2}+\mathrm{O}_{2}$ & $1.50 \mathrm{E}-11$ & -170 & 2 \\
\hline 4 & $\mathrm{NO}_{2}+\mathrm{O}_{3}$ & $\rightarrow$ & $\mathrm{NO}_{3}+\mathrm{O}_{2}$ & $1.20 \mathrm{E}-13$ & -2450 & 1 \\
\hline 5 & $\mathrm{O}_{3}+\mathrm{OH}$ & $\rightarrow$ & $\mathrm{HO}_{2}+\mathrm{O}_{2}$ & $1.70 \mathrm{E}-12$ & -940 & 2 \\
\hline 6 & $\mathrm{HO}_{2}+\mathrm{O}_{3}$ & $\rightarrow$ & $\mathrm{OH}+2 \mathrm{O}_{2}$ & $1.00 \mathrm{E}-14$ & -490 & 2 \\
\hline 7 & $\mathrm{NO}_{3}+\mathrm{NO}$ & $\rightarrow$ & $2 \mathrm{NO}_{2}$ & $1.50 \mathrm{E}-11$ & 170 & 2 \\
\hline 8 & $\mathrm{NO}+\mathrm{HO}_{2}$ & $\rightarrow$ & $\mathrm{NO}_{2}+\mathrm{OH}$ & $3.70 \mathrm{E}-12$ & 250 & 2 \\
\hline 9 & $\mathrm{NO}_{3}+\mathrm{NO}_{2}$ & $\rightarrow$ & $\mathrm{NO}+\mathrm{NO}_{2}+\mathrm{O}_{2}$ & $2.30 \mathrm{E}-12$ & -1000 & 3 \\
\hline 10 & $\mathrm{NO}_{3}+\mathrm{H}_{2} \mathrm{O}_{2}$ & $\rightarrow$ & $\mathrm{HNO}_{3}+\mathrm{HO}_{2}$ & $4.10 \mathrm{E}-16$ & 0 & 3 \\
\hline 11 & $\mathrm{NO}_{3}+\mathrm{NO}_{3}$ & $\rightarrow$ & $2 \mathrm{NO}_{2}+\mathrm{O}_{2}$ & $8.50 \mathrm{E}-13$ & -2450 & 3 \\
\hline 12 & $\mathrm{~N}_{2} \mathrm{O}_{5}+\mathrm{H}_{2} \mathrm{O}$ & $\rightarrow$ & $2 \mathrm{HNO}_{3}$ & $1.30 \mathrm{E}-21$ & 0 & 3 \\
\hline 13 & $\mathrm{OH}+\mathrm{HO}_{2}$ & $\rightarrow$ & $\mathrm{H}_{2} \mathrm{O}+\mathrm{O}_{2}$ & $4.80 \mathrm{E}-11$ & 250 & 1 \\
\hline 14 & $\mathrm{OH}+\mathrm{H}_{2} \mathrm{O}_{2}$ & $\rightarrow$ & $\mathrm{HO}_{2}+\mathrm{H}_{2} \mathrm{O}$ & $2.90 \mathrm{E}-12$ & -160 & 1 \\
\hline 15 & $\mathrm{OH}+\mathrm{H}_{2}$ & $\rightarrow$ & $\mathrm{H}+\mathrm{H}_{2} \mathrm{O}$ & $5.50 \mathrm{E}-12$ & -2000 & 2 \\
\hline 16 & $\mathrm{OH}+\mathrm{HNO}_{3}$ & $\rightarrow$ & $\mathrm{NO}_{3}+\mathrm{H}_{2} \mathrm{O}$ & $9.40 \mathrm{E}-15$ & 778 & 4 \\
\hline 17 & $\mathrm{HO}_{2}+\mathrm{HO}_{2}$ & $\rightarrow$ & $\mathrm{H}_{2} \mathrm{O}_{2}+\mathrm{O}_{2}$ & $2.30 \mathrm{E}-13$ & 600 & 2 \\
\hline 18 & $\mathrm{NO}_{3}+\mathrm{HO}_{2}$ & $\rightarrow$ & $\mathrm{O}_{2}+\mathrm{HNO}_{3}$ & $3.50 \mathrm{E}-12$ & 0 & 2 \\
\hline 19 & $\mathrm{NO}_{3}+\mathrm{HO}_{2}$ & $\rightarrow$ & $\mathrm{OH}+\mathrm{NO}_{2}+\mathrm{O}_{2}$ & $3.50 \mathrm{E}-12$ & 0 & 2 \\
\hline 20 & $\mathrm{HSO}_{3}+\mathrm{O}_{2}$ & $\rightarrow$ & $\mathrm{HO}_{2}+\mathrm{SO}_{3}$ & $4.00 \mathrm{E}-13$ & 0 & 4 \\
\hline 21 & $\mathrm{CH}_{3} \mathrm{O}_{2}+\mathrm{SO}_{2}$ & $\rightarrow$ & $\mathrm{SO}_{3}+\mathrm{CH}_{3} \mathrm{O}$ & $4.00 \mathrm{E}-17$ & 0 & 3 \\
\hline 22 & $\begin{array}{l}\mathrm{SO}_{3}+\mathrm{H}_{2} \mathrm{O} \\
\text { Alkane chemistry }\end{array}$ & $\rightarrow$ & $\mathrm{H}_{2} \mathrm{SO}_{4}$ & $5.00 \mathrm{E}-15$ & 0 & 4 \\
\hline 23 & $\overline{\mathrm{CH}_{4}+\mathrm{OH}}$ & $\rightarrow$ & $\mathrm{CH}_{3}+\mathrm{H}_{2} \mathrm{O}$ & $2.40 \mathrm{E}-12$ & 0 & 2 \\
\hline 24 & $\mathrm{CH}_{3} \mathrm{O}_{2}+\mathrm{NO}$ & $\rightarrow$ & $\mathrm{CH}_{3} \mathrm{O}+\mathrm{NO}_{2}$ & $2.80 \mathrm{E}-12$ & 2 & 2 \\
\hline 25 & $\mathrm{CH}_{3} \mathrm{O}+\mathrm{O}_{2}$ & $\rightarrow$ & $\mathrm{HCHO}+\mathrm{HO}_{2}$ & $3.90 \mathrm{E}-14$ & -900 & 2 \\
\hline 26 & $\mathrm{CH}_{3} \mathrm{O}_{2}+\mathrm{CH}_{3} \mathrm{O}_{2}$ & $\rightarrow$ & $2 \mathrm{CH}_{3} \mathrm{O}+\mathrm{O}_{2}$ & $9.50 \mathrm{E}-14$ & 390 & 2 \\
\hline 27 & $\mathrm{CH}_{3} \mathrm{O}_{2}+\mathrm{CH}_{3} \mathrm{O}_{2}$ & $\rightarrow$ & $\mathrm{CH}_{3} \mathrm{OH}+\mathrm{HCHO}+\mathrm{O}_{2}$ & $1.10 \mathrm{E}-13$ & 365 & 1 \\
\hline 28 & $\mathrm{CH}_{3} \mathrm{O}_{2}+\mathrm{HO}_{2}$ & $\rightarrow$ & $\mathrm{CH}_{3} \mathrm{OOH}+\mathrm{O}_{2}$ & $3.80 \mathrm{E}-13$ & 780 & 1 \\
\hline 29 & $\mathrm{HCHO}+\mathrm{OH}$ & $\rightarrow$ & $\mathrm{HCO}+\mathrm{H}_{2} \mathrm{O}$ & $8.80 \mathrm{E}-12$ & 25 & 1 \\
\hline 30 & $\mathrm{NO}_{3}+\mathrm{HCHO}$ & $\rightarrow$ & $\mathrm{HNO}_{3}+\mathrm{HCO}$ & $5.80 \mathrm{E}-16$ & 0 & 1 \\
\hline \multirow[t]{2}{*}{31} & $\mathrm{HCO}+\mathrm{O}_{2}$ & $\rightarrow$ & $\mathrm{HO}_{2}+\mathrm{CO}$ & $1.50 \mathrm{E}-13$ & 0 & 2 \\
\hline & $\mathrm{CO}+\mathrm{OH}$ & $\rightarrow$ & $\mathrm{CO}_{2}+\mathrm{H}$ & & & \\
\hline 32 & $\mathrm{C}_{2} \mathrm{H}_{6}+\mathrm{OH}$ & $\rightarrow$ & $\mathrm{C}_{2} \mathrm{H}_{5}+\mathrm{H}_{2} \mathrm{O}$ & $7.80 \mathrm{E}-12$ & -1020 & 1 \\
\hline \multirow[t]{2}{*}{33} & $\mathrm{C}_{2} \mathrm{H}_{5}+\mathrm{O}_{2}$ & $\rightarrow$ & $\mathrm{C}_{2} \mathrm{H}_{5} \mathrm{O}_{2}$ & $2.60 \mathrm{E}-12$ & 365 & 2 \\
\hline & $\mathrm{C}_{2} \mathrm{H}_{5} \mathrm{O}_{2}+\mathrm{NO}$ & $\rightarrow$ & $\mathrm{C}_{2} \mathrm{H}_{5} \mathrm{O}+\mathrm{NO}_{2}$ & & & \\
\hline 34 & $\mathrm{C}_{2} \mathrm{H}_{5} \mathrm{O}$ & $\rightarrow$ & $\mathrm{HCHO}+\mathrm{CH}_{3}$ & $3.30 \mathrm{E}+01$ & 0 & 3 \\
\hline 35 & $\mathrm{C}_{2} \mathrm{H}_{5} \mathrm{O}+\mathrm{O}_{2}$ & $\rightarrow$ & $\mathrm{HO}_{2}+\mathrm{CH}_{3} \mathrm{CHO}$ & $9.50 \mathrm{E}-15$ & 0 & 1 \\
\hline 36 & $\mathrm{C}_{2} \mathrm{H}_{5} \mathrm{O}_{2}+\mathrm{CH}_{3} \mathrm{O}_{2}$ & $\rightarrow$ & $\mathrm{C}_{2} \mathrm{H}_{5} \mathrm{O}+\mathrm{CH}_{3} \mathrm{O}+\mathrm{O}_{2}$ & $2.50 \mathrm{E}-14$ & 0 & 3 \\
\hline 37 & $\mathrm{OH}+\mathrm{CH}_{3} \mathrm{CHO}$ & $\rightarrow$ & $\mathrm{H}_{2} \mathrm{O}+\mathrm{CH}_{3} \mathrm{CO}$ & $5.60 \mathrm{E}-12$ & 310 & 1 \\
\hline \multirow[t]{2}{*}{38} & $\mathrm{CH}_{3} \mathrm{CO}+\mathrm{O}_{2}$ & $\rightarrow$ & $\mathrm{CH}_{3} \mathrm{COO}_{2}$ & $2.00 \mathrm{E}-11$ & 0 & 1 \\
\hline & $\mathrm{CH}_{3} \mathrm{COO}_{2}+\mathrm{NO}$ & $\rightarrow$ & $\mathrm{CH}_{3}+\mathrm{CO}_{2}+\mathrm{NO}_{2}$ & & & \\
\hline 39 & $\mathrm{CH}_{3} \mathrm{COO}_{2}+\mathrm{CH}_{3} \mathrm{O}_{2}$ & $\rightarrow$ & $\mathrm{CH}_{3} \mathrm{O}+\mathrm{CH}_{3}+\mathrm{CO}_{2}+\mathrm{O}_{2}$ & $5.50 \mathrm{E}-12$ & 0 & 1 \\
\hline 40 & $\mathrm{C}_{2} \mathrm{H}_{5} \mathrm{O}_{2}+\mathrm{C}_{2} \mathrm{H}_{5} \mathrm{O}_{2}$ & $\rightarrow$ & $2 \mathrm{C}_{2} \mathrm{H}_{5} \mathrm{O}+\mathrm{O}_{2}$ & $9.80 \mathrm{E}-14$ & -110 & 1 \\
\hline 41 & $2 \mathrm{CH}_{3} \mathrm{COO}_{2}$ & $\rightarrow$ & $2 \mathrm{CH}_{3}+\mathrm{O}_{2}+2 \mathrm{CO}_{2}$ & $2.80 \mathrm{E}-12$ & 530 & 1 \\
\hline 42 & $\mathrm{nC}_{4} \mathrm{H}_{10}+\mathrm{OH}$ & $\rightarrow$ & $\operatorname{secC}_{4} \mathrm{H}_{9}+\mathrm{H}_{2} \mathrm{O}$ & $1.40 \mathrm{E}-11$ & -559 & 3 \\
\hline \multirow[t]{2}{*}{43} & $\operatorname{secC}_{4} \mathrm{H}_{9}+\mathrm{O}_{2}$ & $\rightarrow$ & $\operatorname{secC}_{4} \mathrm{H}_{9} \mathrm{O}_{2}$ & $3.00 \mathrm{E}-12$ & 0 & 3 \\
\hline & $\operatorname{secC}_{4} \mathrm{H}_{9} \mathrm{O}_{2}+\mathrm{NO}$ & $\rightarrow$ & $\operatorname{secC}_{4} \mathrm{H}_{9} \mathrm{O}+\mathrm{NO}_{2}$ & & & \\
\hline 44 & $\operatorname{secC}_{4} \mathrm{H}_{9} \mathrm{O}+\mathrm{O}_{2}$ & $\rightarrow$ & $\mathrm{HO}_{2}+\mathrm{CH}_{3} \mathrm{COC}_{2} \mathrm{H}_{5}$ & $2.10 \mathrm{E}-16$ & 0 & 3 \\
\hline 45 & $\mathrm{secC}_{4} \mathrm{H}_{9} \mathrm{O}$ & $\rightarrow$ & $\mathrm{CH}_{3} \mathrm{CHO}+\mathrm{C}_{2} \mathrm{H}_{5}$ & $1.20 \mathrm{E}+03$ & 0 & 3 \\
\hline 46 & $\operatorname{secC}_{4} \mathrm{H}_{9} \mathrm{O}_{2}+\mathrm{CH}_{3} \mathrm{O}_{2}$ & $\rightarrow$ & $\mathrm{secC}_{4} \mathrm{H}_{9} \mathrm{O}+\mathrm{HCHO}+\mathrm{HO}_{2}$ & $2.50 \mathrm{E}-14$ & 0 & 3 \\
\hline 47 & $\mathrm{CH}_{3} \mathrm{COC}_{2} \mathrm{H}_{5}+\mathrm{OH}$ & $\rightarrow$ & $\mathrm{CH}_{3} \mathrm{COCHCH}_{3}+\mathrm{H}_{2} \mathrm{O}$ & $8.80 \mathrm{E}-13$ & 0 & 3 \\
\hline \multirow[t]{2}{*}{48} & $\mathrm{CH}_{3} \mathrm{COCHCH}_{3}+\mathrm{O}_{2}$ & $\rightarrow$ & $\mathrm{CH}_{3} \mathrm{COCHO}_{2} \mathrm{CH}_{3}$ & $3.10 \mathrm{E}-13$ & 0 & 3 \\
\hline & $\mathrm{CH}_{3} \mathrm{COCHO}_{2} \mathrm{CH}_{3}+\mathrm{NO}$ & $\rightarrow$ & $\mathrm{CH}_{3} \mathrm{COCHOCH}_{3}+\mathrm{NO}_{2}$ & & & \\
\hline \multirow[t]{2}{*}{49} & $\mathrm{CH}_{3} \mathrm{COCHOCH}_{3}+\mathrm{O}_{2}$ & $\rightarrow$ & $\mathrm{CH}_{3} \mathrm{COCOCH}_{3}+\mathrm{HO}_{2}$ & $2.50 \mathrm{E}-14$ & 0 & 1 \\
\hline & $\begin{array}{l}\mathrm{CH}_{3} \mathrm{COCHO}_{2} \mathrm{CH}_{3}+\mathrm{CH}_{3} \mathrm{O}_{2} \\
\text { Alkene chemistry }\end{array}$ & $\rightarrow$ & $\mathrm{HCHO}+2 \mathrm{HO}_{2}+\mathrm{CH}_{3} \mathrm{COCOCH}_{3}$ & & & \\
\hline \multirow[t]{2}{*}{50} & $\mathrm{CH}_{2} \mathrm{O}_{2} \mathrm{CH}_{2} \mathrm{OH}+\mathrm{NO}$ & $\rightarrow$ & $\mathrm{CH}_{2} \mathrm{OCH}_{2} \mathrm{OH}+\mathrm{NO}_{2}$ & $3.10 \mathrm{E}-13$ & 0 & 3 \\
\hline & $\mathrm{CH}_{2} \mathrm{OCH}_{2} \mathrm{OH}+\mathrm{O}_{2}$ & $\rightarrow$ & $2 \mathrm{HCHO}+\mathrm{HO}_{2}$ & & & \\
\hline
\end{tabular}




\begin{tabular}{|c|c|c|c|c|c|c|}
\hline 51 & $\mathrm{CH}_{2} \mathrm{O}_{2} \mathrm{CH}_{2} \mathrm{OH}+\mathrm{CH}_{3} \mathrm{O}_{2}$ & $\rightarrow$ & $\mathrm{CH}_{2} \mathrm{OCH}_{2} \mathrm{OH}+\mathrm{CH}_{3} \mathrm{O}+\mathrm{O}_{2}$ & $2.50 \mathrm{E}-14$ & 0 & 3 \\
\hline \multirow[t]{2}{*}{52} & $\mathrm{C}_{2} \mathrm{H}_{4}+\mathrm{O}_{3}$ & $\rightarrow$ & $\mathrm{HCHO}+\mathrm{CH}_{2} \mathrm{O}_{2}$ & \multirow[t]{2}{*}{$1.20 \mathrm{E}-14$} & \multirow[t]{2}{*}{-2630} & \multirow[t]{2}{*}{1} \\
\hline & $\mathrm{CH}_{2} \mathrm{O}_{2}+\mathrm{O}_{2}$ & $\rightarrow$ & $0.42 \mathrm{CO}+0.12 \mathrm{HO}_{2}+0.12 \mathrm{H}_{2}$ & & & \\
\hline 53 & $\mathrm{C}_{3} \mathrm{H}_{6}+\mathrm{O}_{3}$ & $\rightarrow$ & $\mathrm{CH}_{3} \mathrm{CHO}+0.42 \mathrm{CO}+0.12 \mathrm{HO}_{2}+0.12 \mathrm{H}_{2}$ & $6.50 \mathrm{E}-15$ & -1880 & 1 \\
\hline 54 & $\mathrm{C}_{3} \mathrm{H}_{6}+\mathrm{O}_{3}$ & $\rightarrow$ & $\begin{array}{l}\mathrm{HCHO}+0.12 \mathrm{CH}_{4}+0.24 \mathrm{CO}+0.29 \mathrm{HO}_{2}+ \\
0.19 \mathrm{OH}+0.05 \mathrm{CH}_{3} \mathrm{O}+0.43 \mathrm{CH}_{3} \mathrm{O}_{2}\end{array}$ & $6.50 \mathrm{E}-15$ & -1880 & 1 \\
\hline \multirow[t]{2}{*}{55} & $\mathrm{CH}_{3} \mathrm{CHO}_{2} \mathrm{CH}_{2} \mathrm{OH}+\mathrm{NO}$ & $\rightarrow$ & $\mathrm{CH}_{2} \mathrm{CHOCH}_{2} \mathrm{OH}+\mathrm{NO}_{2}$ & \multirow[t]{2}{*}{$3.10 \mathrm{E}-13$} & \multirow[t]{2}{*}{0} & \multirow[t]{2}{*}{3} \\
\hline & $\mathrm{CH}_{2} \mathrm{CHOCH}_{2} \mathrm{OH}+\mathrm{O}_{2}$ & $\rightarrow$ & $\mathrm{HCHO}+\mathrm{CH}_{3} \mathrm{CHO}+\mathrm{HO}_{2}$ & & & \\
\hline \multirow[t]{2}{*}{56} & $\mathrm{CH}_{3} \mathrm{CHO}_{2} \mathrm{CH}_{2} \mathrm{OH}+\mathrm{CH}_{3} \mathrm{O}_{2}$ & $\rightarrow$ & $\mathrm{CH}_{3} \mathrm{CHOCH}_{2} \mathrm{OH}+\mathrm{CH}_{3} \mathrm{O}+\mathrm{O}_{2}$ & \multirow[t]{2}{*}{$2.50 \mathrm{E}-14$} & \multirow[t]{2}{*}{0} & 3 \\
\hline & $\begin{array}{l}\mathrm{CH}_{3} \mathrm{CHOCH}_{2} \mathrm{OH}+\mathrm{O}_{2} \\
\text { Aromatic chemistry }\end{array}$ & $\rightarrow$ & $\mathrm{CH}_{3} \mathrm{CHO}+\mathrm{HCHO}+\mathrm{HO}_{2}$ & & & \\
\hline 57 & $\overline{\mathrm{o}-\mathrm{xylene}+\mathrm{OH}}$ & $\rightarrow$ & product1 & $1.10 \mathrm{E}-11$ & 0 & 3 \\
\hline 58 & product $1+\mathrm{NO}$ & $\rightarrow$ & product $2+\mathrm{NO}_{2}$ & $3.10 \mathrm{E}-13$ & 0 & 3 \\
\hline 59 & product $2+\mathrm{O}_{2}$ & $\rightarrow$ & $\mathrm{HO}_{2}+\mathrm{CH}_{3} \mathrm{COCHO}+\mathrm{CH}_{3} \mathrm{COCH}=\mathrm{C}$ & $\mathrm{HCHO}$ & & 3 \\
\hline & $\mathrm{CH}_{3} \mathrm{COCH}=\mathrm{CHCHO}+\mathrm{OH}$ & $\rightarrow$ & $\mathrm{CH}_{3} \mathrm{COCHOH}-\mathrm{CHO}_{2} \mathrm{CHO}$ & $2.00 \mathrm{E}-11$ & 0 & \\
\hline 60 & $\mathrm{CH}_{3} \mathrm{COCHOH}-\mathrm{CHO}_{2} \mathrm{CHO}+\mathrm{NO}$ & $\rightarrow$ & $\mathrm{NO}_{2}+\mathrm{HO}_{2}+\mathrm{CH}_{3} \mathrm{COCHO}+(\mathrm{HCO})_{2}$ & $3.10 \mathrm{E}-13$ & 0 & 3 \\
\hline 61 & $(\mathrm{HCO})_{2}+\mathrm{OH}$ & $\rightarrow$ & $\mathrm{HO}_{2}+2 \mathrm{CO}+\mathrm{H}_{2} \mathrm{O}$ & $1.10 \mathrm{E}-11$ & 0 & 4 \\
\hline 62 & $\mathrm{CH}_{3} \mathrm{COCHO}+\mathrm{OH}$ & $\rightarrow$ & $\mathrm{CH}_{3} \mathrm{COO}_{2}+\mathrm{CO}+\mathrm{H}_{2} \mathrm{O}$ & $1.70 \mathrm{E}-11$ & 0 & 3 \\
\hline 63 & $\overline{\mathrm{C}_{5} \mathrm{H}_{8}+\mathrm{OH}}$ & $\rightarrow$ & $\mathrm{HOC}_{5} \mathrm{H}_{8}$ & $2.54 \mathrm{E}-11$ & 410 & 3 \\
\hline & $\mathrm{HOC}_{5} \mathrm{H}_{8}+\mathrm{O}_{2}$ & $\rightarrow$ & $\mathrm{HOC}_{5} \mathrm{H}_{8} \mathrm{O}_{2}$ & & & \\
\hline 64 & $\mathrm{HOC}_{5} \mathrm{H}_{8} \mathrm{O}_{2}+\mathrm{NO}$ & $\rightarrow$ & $\mathrm{HOCH}_{2} \mathrm{CH}_{3} \mathrm{COCH}=\mathrm{CH}_{2}+\mathrm{NO}_{2}$ & $3.00 \mathrm{E}-13$ & 0 & 3 \\
\hline & $\mathrm{HOCH}_{2} \mathrm{CH}_{3} \mathrm{COCH}=\mathrm{CH}_{2}+\mathrm{O}_{2}$ & $\rightarrow$ & $\mathrm{CH}_{3} \mathrm{COCH}=\mathrm{CH}_{2}+\mathrm{HCHO}+\mathrm{HO}_{2}$ & & & \\
\hline 65 & $\mathrm{CH}_{3} \mathrm{COCH}=\mathrm{CH}_{2}+\mathrm{OH}$ & $\rightarrow$ & $\mathrm{OHCH}_{3} \mathrm{COCHCH}_{2} \mathrm{O}_{2}$ & $2.00 \mathrm{E}-11$ & 0 & 3 \\
\hline 66 & $\mathrm{OHCH}_{3} \mathrm{COCHCH}_{2} \mathrm{O}_{2}+\mathrm{NO}$ & $\rightarrow$ & $\mathrm{CH}_{3} \mathrm{COCHO}+\mathrm{NO}_{2}+\mathrm{HCHO}+\mathrm{HO}_{2}$ & $3.00 \mathrm{E}-13$ & 0 & 3 \\
\hline 67 & $\mathrm{C}_{5} \mathrm{H}_{8}+\mathrm{O}_{3}$ & $\rightarrow$ & products & $1.20 \mathrm{E}-17$ & 0 & 5 \\
\hline 68 & $\mathrm{C}_{5} \mathrm{H}_{8}+\mathrm{NO}_{3}$ & $\rightarrow$ & products & $3.20 \mathrm{E}-13$ & 0 & 5 \\
\hline 69 & alfa-pinene $+\mathrm{OH}$ & $\rightarrow$ & $\mathrm{PICHO}+\mathrm{HO}_{2}+\mathrm{NO}_{2}+\mathrm{NO}$ & $9.80 \mathrm{E}-12$ & 500 & 6 \\
\hline 70 & alfa-pinene $+\mathrm{NO}_{3}$ & $\rightarrow$ & products & $5.80 \mathrm{E}-12$ & 0 & 6 \\
\hline 71 & alfa-pinene $+\mathrm{O}_{3}$ & $\rightarrow$ & Bir & $4.60 \mathrm{E}-15$ & -1170 & 6 \\
\hline 72 & beta-pinene $+\mathrm{OH}$ & $\rightarrow$ & aldehyde $+\mathrm{HO}_{2}+\mathrm{NO}_{2}-\mathrm{NO}$ & $7.95 \mathrm{E}-11$ & 0 & 7 \\
\hline 73 & beta-pinene $+\mathrm{NO}_{3}$ & $\rightarrow$ & products & $2.36 \mathrm{E}-12$ & 0 & 8 \\
\hline 74 & beta-pinene $+\mathrm{O}_{3}$ & $\rightarrow$ & products & $2.10 \mathrm{E}-17$ & 0 & 5 \\
\hline 75 & 3 -carene $+\mathrm{OH}$ & $\rightarrow$ & $\mathrm{PICHO}+\mathrm{HO}_{2}+\mathrm{NO}_{2}-\mathrm{NO}$ & $1.60 \mathrm{E}-11$ & 500 & 6 \\
\hline 76 & 3 -carene $+\mathrm{NO}_{3}$ & $\rightarrow$ & products & $1.01 \mathrm{E}-11$ & 0 & 6 \\
\hline 77 & 3 -carene $+\mathrm{O}_{3}$ & $\rightarrow$ & products & $6.50 \mathrm{E}-15$ & -1170 & 6 \\
\hline 78 & D-limonene $+\mathrm{OH}$ & $\rightarrow$ & aldehyde $+\mathrm{HO}_{2}+\mathrm{NO}_{2}-\mathrm{NO}$ & $1.69 \mathrm{E}-10$ & 0 & 7 \\
\hline 79 & D-limonene $+\mathrm{NO}_{3}$ & $\rightarrow$ & products & $1.40 \mathrm{E}-11$ & 0 & 7 \\
\hline 80 & D-limonene $+\mathrm{O}_{3}$ & $\rightarrow$ & products & $6.40 \mathrm{E}-16$ & 0 & 5 \\
\hline & Dimethylsulphide chemistry & & & & & \\
\hline 81 & $\overline{\mathrm{CH}_{3} \mathrm{SCH}_{3}+\mathrm{OH}}$ & $\rightarrow$ & $\mathrm{CH}_{3} \mathrm{~S}+\mathrm{CH}_{3} \mathrm{OH}$ & $1.10 \mathrm{E}-11$ & -240 & 9 \\
\hline 82 & $\mathrm{CH}_{3} \mathrm{SCH}_{3}+\mathrm{OH}$ & $\rightarrow$ & $\mathrm{CH}_{3} \mathrm{~S}(\mathrm{OH}) \mathrm{CH}_{3}$ & $1.20 \mathrm{E}-12$ & 0 & 9 \\
\hline 83 & $\mathrm{CH}_{3} \mathrm{~S}(\mathrm{OH}) \mathrm{SH}_{3}$ & $\rightarrow$ & $\mathrm{CH}_{3} \mathrm{SO}+\mathrm{CH}_{4}$ & $5.00 \mathrm{E}-01$ & 0 & 9 \\
\hline 84 & $\mathrm{CH}_{3} \mathrm{~S}+\mathrm{NO}_{2}$ & $\rightarrow$ & $\mathrm{CH}_{3} \mathrm{SO}+\mathrm{NO}$ & $5.60 \mathrm{E}-11$ & 0 & 9 \\
\hline 85 & $\mathrm{CH}_{3} \mathrm{~S}+\mathrm{O}_{3}$ & $\rightarrow$ & $\mathrm{H}_{3} \mathrm{SO}+\mathrm{O}_{2}$ & $5.40 \mathrm{E}-12$ & 0 & 9 \\
\hline 86 & $\mathrm{CH}_{3} \mathrm{~S}+\mathrm{O}_{2}$ & $\rightarrow$ & $\mathrm{CH}_{3} \mathrm{SOO}$ & $6.10 \mathrm{E}-19$ & 0 & 9 \\
\hline 87 & $\mathrm{CH}_{3} \mathrm{SOO}$ & $\rightarrow$ & $\mathrm{CH}_{3} \mathrm{~S}+\mathrm{O}_{2}$ & $1.00 \mathrm{E}+00$ & 0 & 9 \\
\hline 88 & $\mathrm{CH}_{3} \mathrm{~S}(\mathrm{O}) \mathrm{O}_{2}+\mathrm{NO}_{2}$ & $\rightarrow$ & $\mathrm{CH}_{3} \mathrm{~S}(\mathrm{O}) \mathrm{O}_{2} \mathrm{NO}_{2}$ & $5.89 \mathrm{E}-12$ & 0 & 9 \\
\hline 89 & $\mathrm{CH}_{3} \mathrm{~S}(\mathrm{O}) \mathrm{O}_{2} \mathrm{NO}_{2}$ & $\rightarrow$ & $\mathrm{H}_{3} \mathrm{~S}(\mathrm{O}) \mathrm{O}_{2}+\mathrm{NO}_{2}$ & $1.12 \mathrm{E}-02$ & 0 & 9 \\
\hline 90 & $\mathrm{CH}_{3} \mathrm{SOO}$ & $\rightarrow$ & $\mathrm{CH}_{3} \mathrm{SO}_{2}$ & $5.00 \mathrm{E}+00$ & 0 & 9 \\
\hline 91 & $\mathrm{CH}_{3} \mathrm{SOO}+\mathrm{NO}$ & $\rightarrow$ & $\mathrm{CH}_{3} \mathrm{SO}+\mathrm{NO}_{2}$ & $1.11 \mathrm{E}-11$ & 0 & 9 \\
\hline 92 & $\mathrm{CH}_{3} \mathrm{SO}+\mathrm{O}_{3}$ & $\rightarrow$ & $\mathrm{CH}_{3} \mathrm{SO}_{2}$ & $3.00 \mathrm{E}-13$ & 0 & 9 \\
\hline 93 & $\mathrm{CH}_{3} \mathrm{SO}+\mathrm{NO}_{2}$ & $\rightarrow$ & $\mathrm{CH}_{3} \mathrm{SO}_{2}+\mathrm{NO}$ & $1.20 \mathrm{E}-11$ & 0 & 9 \\
\hline 94 & $\mathrm{CH}_{3} \mathrm{SO}+\mathrm{NO}_{2}$ & $\rightarrow$ & $\mathrm{CH}_{3}+\mathrm{SO}_{2}+\mathrm{NO}$ & $8.50 \mathrm{E}-12$ & 0 & 9 \\
\hline 95 & $\mathrm{CH}_{3} \mathrm{SO}+\mathrm{O}_{2}$ & $\rightarrow$ & $\mathrm{CH}_{3} \mathrm{~S}(\mathrm{O}) \mathrm{O}_{2}$ & $7.70 \mathrm{E}-18$ & 0 & 9 \\
\hline 96 & $\mathrm{CH}_{3} \mathrm{~S}(\mathrm{O}) \mathrm{O}_{2}$ & $\rightarrow$ & $\mathrm{CH}_{3} \mathrm{SO}+\mathrm{O}_{2}$ & $1.70 \mathrm{E}+02$ & 0 & 9 \\
\hline 97 & $\mathrm{CH}_{3} \mathrm{~S}(\mathrm{O}) \mathrm{O}_{2}+\mathrm{NO}$ & $\rightarrow$ & $\mathrm{CH}_{3} \mathrm{SO}_{2}+\mathrm{NO}_{2}$ & $2.40 \mathrm{E}-11$ & 0 & 9 \\
\hline 98 & $\mathrm{CH}_{3} \mathrm{SO}_{2}+\mathrm{NO}_{2}$ & $\rightarrow$ & $\mathrm{CH}_{3} \mathrm{SO}_{3}+\mathrm{NO}$ & $1.20 \mathrm{E}-11$ & 0 & 9 \\
\hline 99 & $\mathrm{CH}_{3} \mathrm{SO}_{2}+\mathrm{O}_{3}$ & $\rightarrow$ & $\mathrm{CH}_{3} \mathrm{SO}_{3}+\mathrm{O}_{2}$ & $6.03 \mathrm{E}-13$ & 0 & 9 \\
\hline 100 & $\mathrm{CH}_{3} \mathrm{SO}_{2}+\mathrm{O}_{2}$ & $\rightarrow$ & $\mathrm{CH}_{3} \mathrm{~S}(\mathrm{O})_{2} \mathrm{O}_{2}$ & $2.60 \mathrm{E}-18$ & 0 & 9 \\
\hline 101 & $\mathrm{CH}_{3} \mathrm{~S}(\mathrm{O})_{2} \mathrm{O}_{2}$ & $\rightarrow$ & $\mathrm{CH}_{3} \mathrm{SO}_{2}+\mathrm{O}_{2}$ & $3.30 \mathrm{E}+00$ & 0 & 9 \\
\hline 102 & $\mathrm{CH}_{3} \mathrm{~S}(\mathrm{O})_{2} \mathrm{O}_{2}+\mathrm{NO}_{2}$ & $\rightarrow$ & $\mathrm{CH}_{3} \mathrm{~S}(\mathrm{O})_{2} \mathrm{NO}_{2}+\mathrm{O}_{2}$ & $5.89 \mathrm{E}-12$ & 0 & 9 \\
\hline 103 & $\mathrm{CH}_{3} \mathrm{~S}(\mathrm{O})_{2} \mathrm{NO}_{2}+\mathrm{O}_{2}$ & $\rightarrow$ & $\mathrm{CH}_{3} \mathrm{~S}(\mathrm{O}) \mathrm{O}_{2}+\mathrm{NO}_{2}$ & $1.12 \mathrm{E}-02$ & 0 & 9 \\
\hline 104 & $\mathrm{CH}_{3} \mathrm{~S}(\mathrm{O})_{2}$ & $\rightarrow$ & $\mathrm{CH}_{3}+\mathrm{SO}_{2}$ & $5.00 \mathrm{E}+00$ & 0 & 9 \\
\hline 105 & $\mathrm{CH}_{3} \mathrm{SO}_{3}$ & $\rightarrow$ & $\mathrm{CH}_{3}+\mathrm{SO}_{3}$ & $5.00 \mathrm{E}+00$ & 0 & 9 \\
\hline 106 & $\mathrm{CH}_{3} \mathrm{SO}_{3}$ & $\rightarrow$ & $\mathrm{CH}_{3} \mathrm{SO}_{3} \mathrm{H}$ & $5.01 \mathrm{E}+00$ & 0 & 9 \\
\hline 107 & $\mathrm{CH}_{3} \mathrm{~S}(\mathrm{O})_{2} \mathrm{O}_{2}+\mathrm{NO}$ & $\rightarrow$ & $\mathrm{CH}_{3} \mathrm{SO}_{3}+\mathrm{NO}_{2}$ & $2.40 \mathrm{E}-11$ & 0 & 9 \\
\hline 108 & $\mathrm{CH}_{3} \mathrm{SOO}+\mathrm{O}_{3}$ & $\rightarrow$ & $\mathrm{CH}_{3} \mathrm{SO}+2 \mathrm{O}_{2}$ & 7.94E-13 & 0 & 9 \\
\hline 109 & $\mathrm{CH}_{3} \mathrm{SOO}+\mathrm{NO}_{2}$ & $\rightarrow$ & $\mathrm{CH}_{3} \mathrm{SOONO}_{2}$ & $5.01 \mathrm{E}-12$ & 0 & 9 \\
\hline 110 & $\mathrm{CH}_{3} \mathrm{SOONO}_{2}$ & $\rightarrow$ & $\mathrm{CH}_{3} \mathrm{SOO}+\mathrm{NO}_{2}$ & $1.80 \mathrm{E}+00$ & 0 & 9 \\
\hline 11 & $\mathrm{CH}_{3} \mathrm{~S}+\mathrm{O}_{2}$ & $\rightarrow$ & $\mathrm{CH}_{3}+\mathrm{SO}_{2}$ & $3.00 \mathrm{E}-18$ & 0 & 9 \\
\hline 112 & $\mathrm{CH}_{3} \mathrm{SOO}+\mathrm{O}_{2}$ & $\rightarrow$ & $\mathrm{CH}_{3}+\mathrm{SO}_{2}+\mathrm{O}_{2}$ & $3.00 \mathrm{E}-18$ & 0 & 9 \\
\hline
\end{tabular}




\section{Appendix B}

Reactions rate and rate coefficients for third order reactions ( $1=$ Atkinson et al., 1992; $2=$ Sander et al., 2000; $3=$ Troe, 2001; 4 = JPL Publication 02-25, National Aeronautics and Space Administration, 2003; 5 = Atkinson et al., 1989).

\begin{tabular}{|c|c|c|c|c|c|c|c|c|}
\hline \multirow[b]{2}{*}{ Nr. } & \multirow[b]{2}{*}{ Reactant } & \multirow[b]{2}{*}{$\rightarrow$} & \multirow[b]{2}{*}{ Reaction products } & \multicolumn{4}{|c|}{ Reaction rate } & \multirow[b]{2}{*}{ Ref. } \\
\hline & & & & $\begin{array}{l}k_{0}{ }^{300} \\
k_{\infty}{ }^{300}\end{array}$ & $\begin{array}{l}\mathrm{n} \\
\mathrm{m}\end{array}$ & $\begin{array}{l}E / R \\
E / R\end{array}$ & $\mathbf{F}_{\mathrm{c}}$ & \\
\hline 1 & $\mathrm{O}\left({ }^{3} \mathrm{P}\right)+\mathrm{O}_{2}+[\mathrm{M}]$ & $\rightarrow$ & $\mathrm{O}_{3}+[\mathrm{M}]$ & $\begin{array}{l}5.6 \mathrm{E}-34 \\
2.8 \mathrm{E}-12\end{array}$ & $\begin{array}{c}2.8 \\
0\end{array}$ & $\begin{array}{l}0 \\
0\end{array}$ & $\exp (-\mathrm{T} / 696)$ & 1 \\
\hline 2 & $\mathrm{O}\left({ }^{3} \mathrm{P}\right)+\mathrm{NO}+[\mathrm{M}]$ & $\rightarrow$ & $\mathrm{NO}_{2}+[\mathrm{M}]$ & $\begin{array}{l}9.0 \mathrm{E}-32 \\
3.0 \mathrm{E}-11\end{array}$ & $\begin{array}{c}1.5 \\
0\end{array}$ & $\begin{array}{l}0 \\
0\end{array}$ & 0.6 & 2 \\
\hline 3 & $\mathrm{NO}_{3}+\mathrm{NO}_{2}+[\mathrm{M}]$ & $\rightarrow$ & $\mathrm{N}_{2} \mathrm{O}_{5}+[\mathrm{M}]$ & $\begin{array}{l}2.0 \mathrm{E}-30 \\
1.4 \mathrm{E}-12\end{array}$ & $\begin{array}{l}4.4 \\
0.7\end{array}$ & $\begin{array}{l}0 \\
0\end{array}$ & 0.6 & 2 \\
\hline 4 & $\mathrm{NO}_{2}+\mathrm{OH}+[\mathrm{M}]$ & $\rightarrow$ & $\mathrm{HNO}_{3}+[\mathrm{M}]$ & $\begin{array}{l}3.0 \mathrm{E}-30 \\
3.6 \mathrm{E}-11\end{array}$ & $\begin{array}{l}3 \\
0\end{array}$ & $\begin{array}{l}0 \\
0\end{array}$ & 0.4 & 3 \\
\hline 5 & $\mathrm{~N}_{2} \mathrm{O}_{5}+[\mathrm{M}]$ & $\rightarrow$ & $\mathrm{NO}_{2}+\mathrm{NO}_{3}+[\mathrm{M}]$ & $\begin{array}{l}6.67 \mathrm{E}-04 \\
4.67 \mathrm{E}+14\end{array}$ & $\begin{array}{l}4.4 \\
0.7 \\
\end{array}$ & $\begin{array}{l}10991 \\
10991 \\
\end{array}$ & 0.6 & 2 \\
\hline 6 & $\mathrm{SO}_{2}+\mathrm{OH}+[\mathrm{M}]$ & $\rightarrow$ & $\mathrm{HSO}_{3}+[\mathrm{M}]$ & $\begin{array}{l}3.0 \mathrm{E}-31 \\
1.5 \mathrm{E}-12\end{array}$ & $\begin{array}{c}3.3 \\
0\end{array}$ & $\begin{array}{l}0 \\
0\end{array}$ & 0.6 & 4 \\
\hline 7 & $\mathrm{CH}_{3}+\mathrm{O}_{2}+[\mathrm{M}]$ & $\rightarrow$ & $\mathrm{CH}_{3} \mathrm{O}_{2}+[\mathrm{M}]$ & $\begin{array}{l}4.5 \mathrm{E}-31 \\
1.8 \mathrm{E}-12\end{array}$ & $\begin{array}{c}3 \\
1.7 \\
\end{array}$ & $\begin{array}{l}0 \\
0\end{array}$ & 0.6 & 5 \\
\hline 8 & $\mathrm{CH}_{3} \mathrm{COO}_{2}+\mathrm{NO}_{2}+[\mathrm{M}]$ & $\rightarrow$ & $\mathrm{CH}_{3} \mathrm{COO}_{2} \mathrm{NO}_{2}+[\mathrm{M}]$ & $\begin{array}{l}2.7 \mathrm{E}-28 \\
1.2 \mathrm{E}-11\end{array}$ & $\begin{array}{l}7.1 \\
0.9\end{array}$ & $\begin{array}{l}0 \\
0\end{array}$ & 0.3 & 1 \\
\hline 9 & $\mathrm{CH}_{3} \mathrm{COO}_{2} \mathrm{NO}_{2}+[\mathrm{M}]$ & $\rightarrow$ & $\mathrm{CH}_{3} \mathrm{COO}_{2}+\mathrm{NO}_{2}+[\mathrm{M}]$ & $\begin{array}{l}4.9 \mathrm{E}-03 \\
4.0 \mathrm{E}+16\end{array}$ & $\begin{array}{l}0 \\
0\end{array}$ & $\begin{array}{l}12100 \\
13600 \\
\end{array}$ & 0.3 & 1 \\
\hline 10 & $\begin{array}{c}\mathrm{C}_{3} \mathrm{H}_{6}+\mathrm{OH}+[\mathrm{M}] \\
\{\mathrm{CH} 3 \mathrm{CHCH} 2 \mathrm{OH}+\mathrm{O} 2\end{array}$ & $\begin{array}{l}\rightarrow \\
\rightarrow\end{array}$ & $\begin{array}{c}\mathrm{CH}_{3} \mathrm{CHCH}_{2} \mathrm{OH}+[\mathrm{M}] \\
\mathrm{CH} 3 \mathrm{CHO} 2 \mathrm{CH} 2 \mathrm{OH}\}\end{array}$ & $\begin{array}{l}8.0 \mathrm{E}-27 \\
3.0 \mathrm{E}-11\end{array}$ & $\begin{array}{c}3.5 \\
0 \\
\end{array}$ & $\begin{array}{l}0 \\
0\end{array}$ & $\exp (-\mathrm{T} / 433)$ & 5 \\
\hline 11 & $\begin{array}{l}\mathrm{C}_{2} \mathrm{H}_{4}+\mathrm{OH}+[\mathrm{M}] \\
\left\{\mathrm{CH}_{2} \mathrm{CH}_{2} \mathrm{OH}+\mathrm{O}_{2}\right. \\
\end{array}$ & $\begin{array}{l}\rightarrow \\
\rightarrow\end{array}$ & $\begin{array}{c}\mathrm{CH}_{2} \mathrm{CH}_{2} \mathrm{OH}+[\mathrm{M}] \\
\left.\mathrm{CH}_{2} \mathrm{O}_{2} \mathrm{CH}_{2} \mathrm{OH}\right\} \\
\end{array}$ & $\begin{array}{l}9.5 \mathrm{E}-29 \\
9.0 \mathrm{E}-12 \\
\end{array}$ & $\begin{array}{c}3.1 \\
0\end{array}$ & $\begin{array}{l}0 \\
0 \\
\end{array}$ & $\exp (-\mathrm{T} / 840)$ & 5 \\
\hline
\end{tabular}

\section{Appendix C}

Photochemical reactions

\begin{tabular}{|c|c|c|c|}
\hline Nr. & Reactant & $\rightarrow$ & Reaction products \\
\hline 1 & $\mathrm{O}_{3}+\mathrm{hv}(\lambda<320 \mathrm{~nm})$ & $\rightarrow$ & $\mathrm{O}_{2}+\mathrm{O}\left({ }^{1} \mathrm{D}\right)$ \\
\hline 2 & $\mathrm{O}_{3}+\mathrm{hv}(\lambda>320 \mathrm{~nm})$ & $\rightarrow$ & $\mathrm{O}_{2}+\mathrm{O}\left({ }^{3} \mathrm{P}\right)$ \\
\hline 3 & $\mathrm{NO}_{2}+\mathrm{hv}(\lambda<410 \mathrm{~nm})$ & $\rightarrow$ & $\mathrm{NO}+\mathrm{O}\left({ }^{3} \mathrm{P}\right)$ \\
\hline 4 & $\mathrm{NO}_{3}+\mathrm{hv}(470 \mathrm{~nm}<\lambda<630 \mathrm{~nm})$ & $\rightarrow$ & $\mathrm{NO}_{2}+\mathrm{O}\left({ }^{3} \mathrm{P}\right)$ \\
\hline 5 & $\mathrm{NO}_{3}+\mathrm{hv}(\lambda>580 \mathrm{~nm})$ & $\rightarrow$ & $\mathrm{NO}+\mathrm{O}_{2}$ \\
\hline 6 & $\mathrm{~N}_{2} \mathrm{O}_{5}+\mathrm{hv}(\lambda<350 \mathrm{~nm})$ & $\rightarrow$ & $\mathrm{NO}_{2}+\mathrm{NO}_{3}$ \\
\hline 7 & $\mathrm{H}_{2} \mathrm{O}_{2}+\mathrm{hv}(\lambda<350 \mathrm{~nm})$ & $\rightarrow$ & $2 \mathrm{OH}$ \\
\hline 8 & $\mathrm{HNO}_{3}+\mathrm{hv}(\lambda<320 \mathrm{~nm})$ & $\rightarrow$ & $\mathrm{NO}_{2}+\mathrm{OH}$ \\
\hline 9 & $\mathrm{HCHO}+\mathrm{hv}(\lambda<370 \mathrm{~nm})$ & $\rightarrow$ & $\mathrm{HCO}+\mathrm{H}$ \\
\hline 10 & $\mathrm{HCHO}+\mathrm{hv}(\lambda<370 \mathrm{~nm})$ & $\rightarrow$ & $\mathrm{CO}+\mathrm{H}_{2}$ \\
\hline 11 & $\mathrm{CH}_{3} \mathrm{CHO}+\mathrm{hv}(\lambda<325 \mathrm{~nm})$ & $\rightarrow$ & $\mathrm{CH}_{3} \mathrm{O}_{2}+\mathrm{HO}_{2}+\mathrm{CO}$ \\
\hline 12 & $\mathrm{CH}_{3} \mathrm{COC}_{2} \mathrm{H}_{5}+\mathrm{hv}$ & $\rightarrow$ & $\mathrm{CH}_{3} \mathrm{COO}_{2}+\mathrm{C}_{2} \mathrm{H}_{5} \mathrm{O}_{2}$ \\
\hline 13 & $\mathrm{CH}_{3} \mathrm{COCOCH}_{3}+\mathrm{hv}$ & $\rightarrow$ & $2 \mathrm{CH}_{3} \mathrm{COO}_{2}$ \\
\hline 14 & $\mathrm{HCOCHO}+\mathrm{hv}(\lambda<470 \mathrm{~nm})$ & $\rightarrow$ & $\mathrm{CO}+\mathrm{HCHO}$ \\
\hline 15 & $\mathrm{CH}_{3} \mathrm{OOH}+\mathrm{hv}(\lambda<350 \mathrm{~nm})$ & $\rightarrow$ & $\mathrm{CH}_{3} \mathrm{O}+\mathrm{OH}$ \\
\hline 16 & $\mathrm{CH}_{3} \mathrm{COCHO}+\mathrm{hv}(\lambda<470 \mathrm{~nm})$ & $\rightarrow$ & $\mathrm{CH}_{3} \mathrm{CO}+\mathrm{CO}+\mathrm{HO}_{2}$ \\
\hline
\end{tabular}


Acknowledgements. The QUEST team acknowledge the financial support from the European Commission under the contract number EVK2-CT2001-00127 and the Academy of Finland.

Edited by: K. Hämeri

\section{References}

Atkinson, R., Aschmann, S. M., Winer, A. M., Pitts Jr., J. N.: Kinetics of the gas-phase reactions of $\mathrm{NO}_{3}$ radicals with a series of dialkenes, cycloalkenes, and monoterpenes at $295^{\prime \prime} 1 \mathrm{~K}$, Environ. Sci. Technol., 18, 370-375, 1984.

Atkinson, R. and Lloyd, A.: Evaluation of kinetic and mechanistic data for modeling of photochemical smog, J. Phys. Chem. Ref. Data, 13(2) , 315-344, 1984.

Atkinson, R., Aschmann, S. M., and Pitts Jr., J. N.: Rate constants for the gas-phase reactions of the $\mathrm{OH}$ radical with a series of monoterpenes at 294" 1 K, Int. J. Chem. Kin., 18, 287-299, 1986.

Atkinson, R., Baulch, D. L., Cox, R. F., Kerr, J. A., and Troe, J.: Evaluated kinetic and photochemical data for atmospheric chemistry: supplement III IUPAC subcommittee on gas kinetic data evaluation for atmospheric chemistry, J. Phys. Chem. Ref. Data, 18, 881-1097, 1989.

Atkinson, R., Aschmann, S. M., and Arey, J.: Rate constants for the gas-phase reactions of $\mathrm{OH}$ and $\mathrm{NO} 3$ radicals and $\mathrm{O}$ with sabinene and camphene at 296"2 K, Atmos. Environ., 24A, 2647-2654, 1990.

Atkinson, R., Baulch, D. L., Cox, R. F., Kerr, J. A., and Troe, J.: Kinetic and photochemical data for 3 atmospheric chemistry, J. Phys. Chem. Ref. Data, 21, 1125-1567, Suppl. IV, 1992.

Baulch, D. L., Cox, R. A., Crutzen, P. J., Hampson Jr., R. F., Kerr, J. A., Troe, J., and Watson, R. T.: Evaluated kinetic and photochemical data for atmospheric chemistry, J. Phys. Chem. Ref. Data, 11, 327-496, Suppl. I, 1982.

Blackadar, A.: Advances in Environmental Science and Engineering, Vol. 1, Chap.: High-resolution models of the planetary boundary layer, pp. 50-85, Gordon and Breech Science Publishers, Inc., New York, 1979.

Boy, M., Rannik, U., Lehtinen, K. E. J., Tarvainen, V., Hakola, H., and Kulmala, M.: Nucleation events in the continental PBL long term statistical analyses of aerosol relevant characteristics, J. Geophys. Res., 108(D21), 4667, doi:10.1029/2003JD003838, 2003.

Boy, M., Petäjä, T., Dal Maso, M., Rannik, Ü., Rinne, J., Aalto, P., Laaksonen, A., Vaattovaara, P., Joutsensaari, J., Hoffmann, T., Warnke, J., Apostolaki, M., Stephanou, E. G., Tsapakis, M., Kouvarakis, A., Pio, C., Carvalho, A., Römpp, A., Moortgat, G., Spirig, C., Guenther, A., Greenberg, J., Ciccioli, P., and Kulmala, M.: Overview of the field measurement campaign in Hyytiälä, August 2001 in the framework of the EU project OSOA, Atmos. Chem. Phys., 4, 657-678, 2004,

http://www.atmos-chem-phys.net/4/657/2004/.

Boy, M., Kulmala, M., Ruuskanen, T. M., Pihlatie, M., Reissell, A., Aalto, P. P., Keronen, P., Dal Maso, M., Hellen, H., Hakola, H., Jansson, R., Hanke, M., and Arnold, F.: Sulphuric acid closure and contribution to nucleation mode particle growth, Atmos. Chem. Phys., 5, 863-878, 2005, http://www.atmos-chem-phys.net/5/863/2005/.
Degrazia, G., Rizza, U., Mangia, C., and Tirabassi, T.: Validation of a new turbulent parameterization for dispersion models in convective conditions, Boundary-Layer Meteorol., 85, 243-254, 1997a.

Degrazia, G., Velho, H. C., and Carvalho, J.: Nonlocal exchange coefficients for the convective boundary derived from spectral properties, Contr. Atmos. Phys., 70, 57-64, 1997b.

Degrazia, G., Mangia, C., and Rizza, U.: A comparison between different methods to estimate the lateral dispersion parameter under convective conditions, J. Appl. Meteorol., 37, 227-231, 1998.

Degrazia, G., Moreira, D., and Vilhena, M.: Derivation of an eddy diffusivity depending on source distance for vertically inhomogeneous turbulence in a convective boundary layer, J. Appl. Meteor., 40, 1233-1240, 2001.

Fielder, V., Dal Maso, M., Boy, M., Aufmhoff, H., Hoffmann, J., Schuck, T., Birmili, W., Hanke, M., Uecker, J., Arnold, F., and Kulmala, M.: The contribution of sulphuric acid to atmospheric particle formation and growth: a comparison between boundary layers in Northern and Central Europe, Atmos. Chem. Phys., 5, 1773-1785, 2005, http://www.atmos-chem-phys.net/5/1773/2005/.

Finkelstein, P. L., Ellestad, T. G., Clarke, J. F., Meyers, T. P., Schwede, D. B., Hebert, E. O., Neal, J. A.: Ozone and sulfur dioxide dry deposition to forests: Observations and model evaluation, J. Geophys. Res., 105(D12), 15, 15 365-15 377, 2000.

Finlayson-Pitts, B. J. and Pitts Jr, J. N.: Atmospheric Chemistry: Fundamentals and Experimental Techniques, Wiley, Chichester, 1986.

Holtslag, A., van Meijgaard, E., and Rooy, W. D.: A comparison of boundary layer diffusion schemes in unstable conditions over land, Boundary-Layer Meteorol., 76, 69-95, 1995.

Horii, C. V., Munger, J. W., Wofsy, S. C., Zahniser, M., Nelson, D., and McManus, J. B.: Fluxes of nitrogen oxides over a temperate deciduous forest, J. Geophys. Res., 109, D08305, doi:10.1029/2003JD004326, 2004.

Janson, R.: Monoterpenes from the boreal coniferous forest, their role in atmospheric chemistry, $\mathrm{PhD}$ thesis, 1992.

Jenkin, M. E., Shallcross, D. E., and Harvey, J. N.: Development and application of a possible mechanism for the generation of cis-pinic acid from the ozonolysis of a- and b-pinene, Atmos. Environ., 34, 2837-2850, 2000.

Karl, T., Harley, P., Guenther, A., Rasmussen, R., Baker, B., Jardine, K., and Nemitz, E.: The bi-directional exchange of oxygenated VOCs between a loblolly pine (Pinus taeda) plantation and the atmosphere, Atmos. Chem. Phys., 5, 3015-3031, 2005, http://www.atmos-chem-phys.net/5/3015/2005/.

Kerminen, V. M., Lihavainen, H., Komppula, M., Viisanen, Y., and Kulmala, M.: Direct observational evidence linking atmospheric aerosol formation and cloud droplet activation, J. Geophys. Res., 32, L14803, doi:10.1029/2005GL0231130, 2005.

Komppula, M., Dal Maso, M., Lihavainen, H., Kulmala, M., and Viisanen, Y.: Comparison of new particle formation events at two locations in Northern Finland, J. Aerosol Sci., EAC Abstracts, S743-S744, $11417,2003$.

Kondo, J. and Matsushima, D.: A simple parameterization if longwave radiative cooling with application to the atmospheric boundary layer for clear sky conditions, Boundary-Layer Meteorol., 64, 209-229, 1993. 
Korhonen, H., Lehtinen, K. E. J., and Kulmala, M.: Multicomponent aerosol dynamics model UHMA: modle development and validation, Atmos. Chem. Phys., 4, 471-506, 2004, http://www.atmos-chem-phys.net/4/471/2004/.

Kulmala, M., Laaksonen, A., and Pirjola, L.: Parametrizations for sulfuric acid/water nucleation rates, J. Geophys. Res., 103, 83018308, 1998.

Kulmala, M., Haemeri, K. K., Aalto, P., Maekelae, J., Pirjola, L., Nilsson, E. D., Buzorius, G., Rannik, U., Dal Maso, M., Seidl, W., Hoffmann, T., Jansson, R., Hansson, H.-C., O’Dowd, C., and Viisanen, Y.: Overview of the international project on biogenic aerosol formation in the boreal forest (BIOFOR), Tellus B, 53, 324-343, 2001.

Kulmala, M., Vehkamaeki, H., Petaejae, T., Dal Maso, M., Lauri, A., Kerminen, V.-M., Birmili, W., and McMurry, P. H.: Formation and growth rates of ultrafine atmospheric particles: A observations, J. Aerosol Sci., 35, 143-176, 2004a.

Kulmala, M., Kerminen, V.-M., Anttila, T., Laaksonen, A., and O'Dowd, C. D.: Organic aerosol formation via sulphate cluster activation, J. Geophys. Res., 109(D4), 4205, doi:10.1029/2003JD003961, 2004b.

Kulmala, M., Lehtinen, K. E. J., and Laaksonen, A.: Why formation rate of $3 \mathrm{~nm}$ particles depends linearly on sulphuric acid concentration?, Atmos. Chem. Phys. Discuss., 5, 11 277-11 293, 2005.

Langford, A. O. and Fehsenfeld, F. C.: Natural vegetation as a source or sink for atmospheric ammonia: a case study, Science, 255, 581-583, 1992.

Lohmann, U. and Feichter, J.: Global indirect aerosol effects: a review, Atmos. Chem. Phys., 5, 715-737, 2005, http://www.atmos-chem-phys.net/5/715/2005/.

Lovejoy, E. R., Curtius, J., and Froyd, K. D.: Atmospheric ioninduced nucleation of sulfuric acid and water, J. Geophy. Res., 109, D08204, doi:1029/2003JD004460, 2004.

Lüpkes, C. and Schlünzen, K., Modelling the arctic convective boundary-layer with different turbulence parameterizations, Boundary-Layer Meteorol., 79, 107-130, 1996.

Mellor, G. and Yamada, T., A hierarchy of turbulence closure models for planetary boundary layers, J. Atmos. Sci., 31, 1791-1806, 1974.

Mikkelson, T. N., Ro-Paulsen, H., Hovmand, M. F., Jensen, N. O., Pilegaard, K., and Egleov, A. H.: Five-year measurements of ozone fluxes to a Danish Norway spruce canopy, Atmos. Environ., 38, 2361-2371, 2004.

Napari, I., Noppel, M., Vehkamaeki, H., and Kulmala, M.: An improved model for ternary nucleation of sulfuric-acid-ammonia water, J. Chem. Phys., 116, 4221-4227, 2002.

O'Dowd, C. D., Yoon, Y. J., Junkermann, W., Aalto, P. P., and Lihavainen, H.: Airborne measurements of nucleation mode particles II: Boreal Forest Events, Report Series in Aerosol Science, Nr. 76, ISBN 952-5027-63-5, p. 162-173, 2005.

Press, W. H., Flannery, B. P., Teukolsky, S. A., and Vetterling, W. T.: "Runge-Kutta Method" and "Adaptive Step Size Control for Runge-Kutta", Cambridge University Press, §16.1 and 16.2,
704-716, 1992.

Ramanathan, V., Crutzen, P. J., Kiehl, J. T., and Rosenfeld, D.: Aerosols, climate, and the hydrological cycle, Science, 294, 2119-2124, 2001.

Rannik, U., Aalto, P., Keronen, P., Vesala, T., and Kulmala, M.: Interpretation of aerosol particle fluxes over a pine forest: Dry deposition and random errors, J. Geophys. Res., 108(D17), 4544, doi:10.1029/2003JD003542, 2003.

ReVelle, D.: Chaos and "bursting" in the planetary boundary layer, J. Appl. Meteor., 32, 1169-1180, 1993.

Saltelli, A. and Hjorth, J.: Uncertainty and sensitivity analyses of OH-initiated dimethyl sulphide DMS oxidation kinetics, J. Atmos. Chem., 21, 187-221, 1995.

Sihto, S.-L., Kulmala, M., Kerminen, V.-M., Dal Maso, M., Petäjä, Riipinen, T., I., Korhonen, H., Arnold, F., Janson, R., Boy, M., Laaksonen, A., and Lehtinen, K. E. J.: Atmospheric sulphuric acid and aerosol formation: implications from atmospheric measurements for nucleation and early growth mechanisms, Atmos. Chem. Phys., 6, 4079-4091, 2006,

http://www.atmos-chem-phys.net/6/4079/2006/.

Simpson, D.: Long-period modelling of photochemical oxidants in Europe: model calculation for July 1985, Atmos. Environ., 26A, 1609-1634, 1992.

Stratmann, F., Siebert, H., Spindler, G., Wehner, B., Althausen, D., Heintzenberg, J., Hellmuth, O., Rinke, R., Schmieder, U., Seidel, C., Tuch, T., Uhrner, U., Wiedensohler, A., Wandinger, U., Wendisch, M., Schell, D., and Stohl, A.: New-particle formation events in a continental boundary layer: First results from the SATURN experiment, Atmos. Chem. Phys., 3, 1445-1459, 2003, http://www.atmos-chem-phys.net/3/1445/2003/.

Stull, R.: An Introduction to Boundary Layer Meteorology, Kluwer Academic Publishers, Dordrecht/Boston/London, 1997.

Swinbank, W.: Long-wave radiation from clear skies, Q. J. Roy. Meteor. Soc., 89, 339-348, 1963.

Turnipseed, A. A., Huey, L. G., Nemitz, E., Stickel, R., Higgs, J., Tanner, D. J., Slusher, D. L., Sparks, J. P., Flocke, F., and Guenther, A.: Eddy covariance fluxes of peroxyacetyl nitrates (PANs) and $\mathrm{NO}_{\mathrm{y}}$ to a coniferous forest, J. Geophys. Res., 111, D09304, doi:10.1029/2005JD006631, 2006.

Weber, R. J., Marti, J. J., McMurry, P. H., Eisele, F. L., Tanner, D. J., and A. Jefferson: Measured atmospheric new particle formation rates: implications for nucleation mechanisms, Chem., Eng. Comm., 151, 53-64, 1996.

Wehner, B., Petaja, T., Boy, M., Engler, C., Birmili, W., Tuch, T., Wiedensohler, A., and Kulmala, M.: The contribution of sulphuric acid and non-volatile compounds on the growth of freshly formed atmospheric aerosols, Geophys. Res. Lett., 32, L17810, doi:10.1029/2005GL023827, 2005.

Wesely, M. L.: Parameterizaton of surface resistances to gaseous dry deposition in regional-scale numerical models, Atmos. Environ., 23(6), 1293-1304, 1989. 